OPEN ACCESS

Edited by:

Yuling Qiu,

Tianjin Medical University, China

Reviewed by:

Yu Cai,

Jinan University, China

Rong-Rong He, Jinan University,

China

*Correspondence:

Changgang Sun

scgdoctor@126.com

${ }^{\dagger}$ These authors have contributed equally to this work

Specialty section:

This article was submitted to

Pharmacology of Anti-Cancer Drugs,

a section of the journal

Frontiers in Oncology

Received: 06 May 2021 Accepted: 31 May 2021

Published: 21 June 2021

Citation:

Jiang $W$, Xia T, Liu C, Li J, Zhang W and Sun $C$ (2021) Remodeling the Epigenetic Landscape of

Cancer-Application Potential

of Flavonoids in the Prevention and Treatment of Cancer.

Front. Oncol. 11:705903.

doi: 10.3389/fonc.2021.705903

\section{Remodeling the Epigenetic Landscape of Cancer-Application Potential of Flavonoids in the Prevention and Treatment of Cancer}

\author{
Weiyi Jiang ${ }^{1 \dagger}$, Tingting Xia ${ }^{1 \dagger}$, Cun Liu ${ }^{1}$, Jie $\mathrm{Li}^{1}$, Wenfeng Zhang $^{2}$ and Changgang Sun ${ }^{3,4 *}$ \\ ${ }^{1}$ College of First Clinical Medicine, Shandong University of Traditional Chinese Medicine, Jinan, China, ${ }^{2}$ Clinical Medical \\ Colleges, Weifang Medical University, Weifang, China, ${ }^{3}$ Department of Oncology, Weifang Traditional Chinese Hospital, \\ Weifang, China, ${ }^{4}$ Qingdao Academy of Chinese Medical Sciences, Shandong University of Traditional Chinese Medicine, \\ Qingdao, China
}

Epigenetics, including DNA methylation, histone modification, and noncoding RNA regulation, are physiological regulatory changes that affect gene expression without modifying the DNA sequence. Although epigenetic disorders are considered a sign of cell carcinogenesis and malignant events that affect tumor progression and drug resistance, in view of the reversible nature of epigenetic modifications, clinicians believe that associated mechanisms can be a key target for cancer prevention and treatment. In contrast, epidemiological and preclinical studies indicated that the epigenome is constantly reprogrammed by intake of natural organic compounds and the environment, suggesting the possibility of utilizing natural compounds to influence epigenetics in cancer therapy. Flavonoids, although not synthesized in the human body, can be consumed daily and are common in medicinal plants, vegetables, fruits, and tea. Recently, numerous reports provided evidence for the regulation of cancer epigenetics by flavonoids. Considering their origin in natural and food sources, few side effects, and remarkable biological activity, the epigenetic antitumor effects of flavonoids warrant further investigation. In this article, we summarized and analyzed the multidimensional epigenetic effects of all 6 subtypes of flavonoids (including flavonols, flavones, isoflavones, flavanones, flavanols, and anthocyanidin) in different cancer types. Additionally, our report also provides new insights and a promising direction for future research and development of flavonoids in tumor prevention and treatment via epigenetic modification, in order to realize their potential as cancer therapeutic agents.

Keywords: flavonoids, natural compounds, phytochemicals, epigenetic, epigenome, cancer, HDAC, DNMT 


\section{INTRODUCTION}

Cancer is a chronic consumptive disease that has not been overcome yet and has become a global health problem threatening human life $(1,2)$. Developments in the field of oncology suggest that cancer is regulated not only by genetics but also by epigenetic programming (3). First, epigenetic mechanisms can circumvent changes in the DNA sequence and directly target the expression of proto-oncogenes and tumor suppressor genes to induce carcinogenesis $(4,5)$. Second, epigenetic abnormalities occur in the early stage of carcinogenesis and precede mutations which also occur in somatic cells (6); therefore, such mechanisms have become a new therapeutic avenue to conquer tumors. More importantly, in the complex and multi-dimensional process of carcinogenesis, these mechanisms, which differ from genetics, are frequently bidirectional and reversible (7). And defects of epigenetics are largely a consequence of lifestyle and habits such as inadequate consumption of natural compounds, smoking, and drinking (8, 9), and they can also reverse abnormal epigenetic effects through proper intake of natural compounds $(10,11)$. These facts make epigenetics attractive for the development of new treatments.

Flavonoids are phytochemicals that are frequently consumed on a daily basis. Because of their remarkable biological activities, flavonoids have recently attracted scientific interest as they are beneficial to health and reduce the risk of disease $(12,13)$. In the field of cancer, evidence of cancer treatment effects of flavonoids through epigenetic pathways is continuously being investigated. For example, kaempferol, which occurs in grapefruit, broccoli, and other plants, can regulate the activity of histone deacetylase (HDAC) in various cancers (14). Epigallocatechin-3-gallate (EGCG) in tea can affect expression of DNA methyltransferases, HDACs, and noncoding RNAs in cancer cells (15-17). Key evidence such as this improves our understanding of the importance of diet for cancer prevention and suggests the potential of dietary flavonoids for epigenetic therapy against cancer.

Epigenetic mechanisms of cancer have been described in detail in previous studies $(18,19)$. Thus, we review the core mechanism of epigenetics and abnormal regulation in cancer to provide a clear groundwork. Recent research progress regarding anticancer efficacy of all types of flavonoids targeting epigenetic regulation pathways is reviewed here, and their potential for cancer prevention and treatment is elaborated to provide evidence for the anticancer effects of food and improve the understanding of respective epigenetic mechanisms to support the development of new treatment strategies and chemoprophylaxes.

\section{EPIGENETICS AND CANCER}

Epigenetics are heritable changes in gene expression without alterations in DNA sequences. There are numerous such phenomena, including DNA methylation, histone modification, genomic imprinting, maternal effects, and RNA editing (20). However, regarding physiological and pathological gene regulation of mammals, epigenetic effects predominantly refer to three aspects, i.e., DNA methylation, histone modification, and noncoding RNA regulation (21). Flavonoids also regulate cancer epigenetic abnormalities through these three aspects.

\section{DNA Methylation}

In the field of epigenetics, DNA methylation regulation is the most studied mechanism which can directly modify gene expression without changing genetic information and participates in various biological processes such as genomic stability, regulation of gene transcription, embryonic development, and tumorigenesis (22-24). DNA methylation modifications are common in human genomic DNA, covalently binding methyl groups to the fifth carbon in the cytosine group of $\mathrm{CpG}$ dinucleotides to form 5-methylcytosine. CpG dinucleotides are distributed inhomogeneously in the human genome and are more abundant in promoter regions of genes (25). Gene regions with a higher proportion of $\mathrm{CpG}$ are termed $\mathrm{CpG}$ islands and occur in promoters of more than $60 \%$ of genes (26). Hypermethylation of a promoter $\mathrm{CpG}$ island can inactivate the gene, whereas promoter $\mathrm{CpG}$ islands of transcriptionally active DNA sequences are typically not methylated (18). For example, even though the vast majority of $\mathrm{CpG}$ islands in developmental and differentiated tissues remain methylated, a small number of $\mathrm{CpG}$ islands are methylated in a tissue-specific manner to inhibit gene expression (27). In a few cases, DNA hypermethylation can lead to abnormal gene activation. This abnormal regulation has been described in detail in other reports (28), however, in-depth elaboration of this process is beyond the scope of this review.

DNA methylation requires catalysis by DNA methyltransferases (DNMTs) (29). Five types of DNMTs including DNMT1, DNMT3a, DNMT3b, DNMT2, and DNMT3L have been identified (30). The first three types are considered to exert methyltransferase activity: DNMT1 is mainly responsible for maintenance methylation (i.e., identifying the DNA strand that has been methylated and then methylating the complementary strand), while Dnmt3a and Dnmt3b are involved in de novo methylation to methylate unmethylated DNA double-strands (31). Abnormal DNA methylation leads to epigenetic imbalance which is an important mechanism underlying tumorigenesis (32). Compared with somatic cells, cancer cells are hypermethylated in the promoter regions of multiple cancer suppressor genes (e.g. MGMT, CdH1, E-cadherin, BRCA1) which is considered a common regulator of transcriptional silencing of tumor suppressor genes, while hypomethylation is observed in the whole genome of cancer cells and is associated with upregulated expression of proto-oncogenes (such as cyclinD2, PAX2, PAX2, and $\mathrm{ABCB} 1)(33,34)$. Most flavonoids exert strong effects on DNA methylation (Figure 1), and hesperidin and naringenin are candidate drugs that inhibit DNMTs.

\section{Histone Modification}

In addition to DNA methylation which occurs directly on gene sequences, the chromatin structure is also affected by histone modification which is associated with DNA replication, transcription, and repair through histone-DNA or histonehistone interaction (35). Histones are basic proteins of 


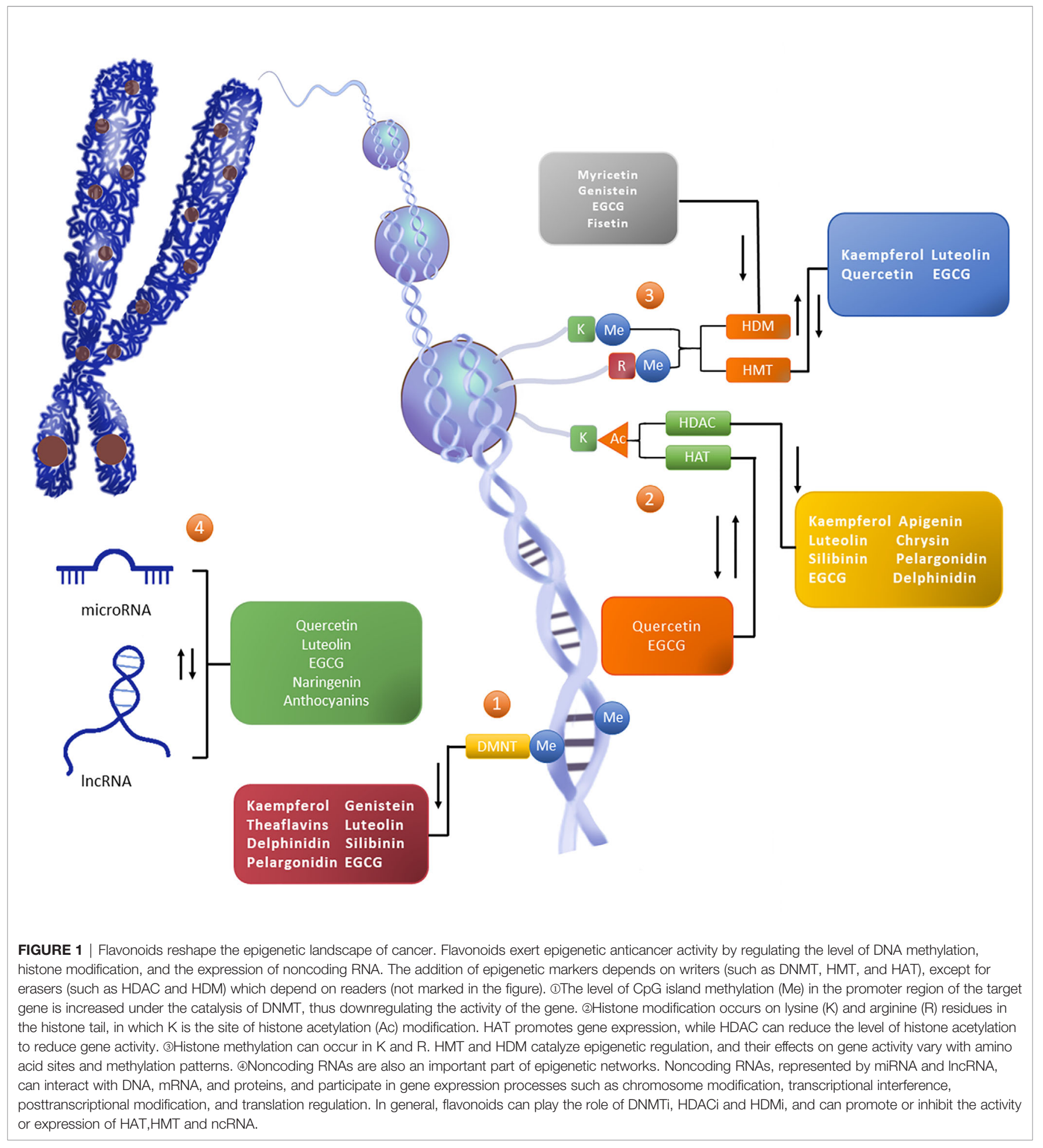

eukaryotes that bind to chromosomal DNA. A histone octamer formed by two molecules of $\mathrm{H} 2 \mathrm{~A}$ and $\mathrm{H} 2 \mathrm{~B}$ and two molecules of $\mathrm{H} 3$ and $\mathrm{H} 4$, together with 147 base pairs of DNA form nucleosomes which participate in the formation of chromosomes (36). Histones in nucleosomes can undergo a variety of epigenetic regulation through the free $\mathrm{N}$-terminal.
According to the different modes of action, histone modification can be assigned to methylation, acetylation, phosphorylation, adenylation, ubiquitin, and ADP ribosylation (37). Acetylation and methylation are well-studied regulation modes $(36,38)$, which are also the main histone modifications mode of natural anti-tumor drug flavonoids (Figure 1). 


\section{Histone Acetylation}

Histone acetylation is the best characterized histone modification and plays an important role in gene regulation, chromatin structure, and tumorigenesis (39-41). It is generally accepted that high acetylation activates and low acetylation inhibits gene expression (42-44). Histone acetylation is frequently modified on $\mathrm{N}$-terminal lysine sites of $\mathrm{H} 3$ and $\mathrm{H} 4$ and is regulated by histone acetyltransferase (HAT) and $\operatorname{HDAC}(18,45)$. There are three HAT families, i.e., the Gcn5-related N-acetyltransferase (GNAT) family which occurs in the nucleus and is associated with transcription; the MYST family, mainly comprising Ybf2-Sas3, Sas2, MOZ, and Tip60, which occur in the cytoplasm and participate in posttranslational modification; and the $\mathrm{p} 300 / \mathrm{cbp}$ family which is responsible for transcription and posttranslational modification $(46,47)$. Based on structural characteristics and catalysis, HDACs are assigned to the following four categories - class I: HDAC1, 2, 3, and 8; class II: HDAC4, 5, 6, 7, 9, and 10; class III: sirtuins (SIRT17); and class IV: HDAC11. HDACs such as those of classes I, II, and IV show structural homology and require zinc ions to activate their catalytic effects, while sirtuins require NAD+ as a cofactor to exert catalysis (48).

Histone acetylation plays an important role in the development of cancer. HDAC and HAT can interact with proto-oncogenes and tumor suppressor genes and thereby interfere with the regulation of these genes during tumor cell proliferation, metastasis, and apoptosis (49, 50). For example, during promyelocytic leukemia, the mSin3-HDAC complex can deacetylate key genes and block transcription, leading to tumorigenesis. An imbalance in HAT activity can also lead to cancer. For example, p300/cbp can be reduced by the binding of viral oncoprotein (E1A), indicating the relationship between HAT and tumorigenesis.

\section{Histone Methylation}

Methylation is also involved in epigenetic regulation of histones. The N-terminal lysine and arginine residues of $\mathrm{H} 3$ and $\mathrm{H} 4$ are reversibly modified through catalysis of histone methyl invertase (HMT) and histone demethylase (HDM) (51). Histone methylation regulates the silencing and activation of gene transcription, and the specific biological behavior depends on the amino acid residue sites (different parts of lysine or arginine) and on the form of methylation (monomethylation, dimethylation, or trimethylation) (52). For example, methylation at lysine 9 (H3K9) of histone $\mathrm{H} 3$ leads to transcriptional inhibition, whereas trimethylation at lysine $\mathrm{K} 4$ (H3K4) and at K9 (H3K9) of histone $\mathrm{H} 3$ is responsible for transcriptional activation $(53,54)$. Imbalances in histone methylation and demethylation are closely associated with cancer. For example, MLL1 can cause H3K4 methylation, leading to acute lymphoblastic leukemia (55); LSD1 is both a classical oncogene and an active lysine demethylase(KDM) that removes the methyl group from $\mathrm{H} 3 \mathrm{~K} 4$ and $\mathrm{H} 3 \mathrm{~K} 9$ sites and is considered a therapeutic target for acute leukemia cases (56).

\section{Regulation of Noncoding RNA miRNA}

The current understanding of miRNAs suggests that they are important epigenetic vectors and key factors in anticancer- targeting regulation by flavonoids. miRNAs, which comprise approximately 22 nucleotides, are single-stranded RNAs that are responsible for posttranscriptional silencing of target genes, thereby regulating cell proliferation, differentiation, migration, and other biological processes. As effectors of negative regulation of gene transcription, miRNAs participate in the expression of genetic information in two ways; first, perfect pairing of miRNA transcriptional sequences genes leads to degradation of the target mRNA and interrupts mRNA translation; second, miRNAs may inhibit the transcription process by binding to the incomplete complementary site of the 3 '-untranslated region of mRNA. miRNAs can regulate $1 / 3$ human gene and form a complex regulatory network with target genes. A given miRNA may correspond to multiple target genes, and a target gene may also be regulated by multiple miRNAs (57-59).

There is increasing evidence for the relationship between miRNAs and cancer. miRNA expression profiles can be used to distinguish normal tissue from cancerous tissue and to classify different types of cancer $(60,61)$. In addition, miRNAs play a role in carcinogenic and tumor-inhibitory signaling pathways, e.g., miRNAs of the miR-34 family act as a signal regulator in the p53 pathway, and miR-16 negatively regulates mitogenic signals and blocks the cell cycle. Interestingly, regulation of miRNAs in cancer is also affected by DNA methylation and histone modification, as discussed above. For example, hypermethylation of miR-9-1 was observed in breast cancer, and the MIR-17-92 cluster in hepatocellular carcinoma may be regulated by HDAC inhibitors $(62,63)$. Taken together, epigenetics is not an isolated complex of processes but a multilevel interrelated regulatory network, and miRNAs play an indispensable role in this regulatory mechanism.

\section{IncRNA}

Unlike miRNA, lncRNA, which is noncoding RNA exceeding 200 bp in length, is well-known for its regulatory effects on the cell cycle, cell differentiation, and epigenetic effects on biological processes $(64,65)$. Some recent studies examined epigenetic effects of lncRNAs. Their long chain structures enable lncRNAs to form complex secondary and tertiary structures which can bind to DNA, RNA, or proteins, reshape chromatin structures, and participate in transcriptional and posttranscriptional regulation (66-68). Although the specific functions of lncRNAs remain to be elucidated, their unregulated expression patterns have been shown to be related to diseases such as cancer. This type of long-chain RNA participates in malignant mechanisms such as proliferation, migration, and drug resistance and is of clinical importance regarding early diagnosis and prognosis of tumors (69). For example, IncRNA-p21 can induce apoptosis. Highly upregulated in liver cancer is considered a potential biomarker for breast cancer with liver metastasis. High expression of HOX antisense intergenic RNA in breast cancer is associated with invasiveness. lncRNAs have become one of the core targets of tumor research as they may be highly informative regarding cancer. lncRNA therapy can be an adequate tumor treatment option, and dietary phytochemicals such as flavonoids have been examined in the past few years to assess their therapeutic potential to regulate lncRNAs (Figure 1). 


\section{EPIGENETIC EFFECTS OF FLAVONOIDS DURING CANCER}

Cancer is affected by interactions of genetics and epigenetics (1). Compared with the genome, the epigenome is often affected by acquired factors such as environment and diet $(70,71)$. To date, more than 4,000 flavonoids have been identified in plants, and these compounds are common in vegetables, fruits, and tea. The role of flavonoids in the treatment of diseases has been studied extensively (72-74). Prophylactic flavonoids can chemically reverse adverse epigenetic marking in cancer cells, which may inspire researchers to explore novel avenues of cancer prevention and early treatment (73).

Flavonoids, the largest group of secondary metabolites in the polyphenol family, are produced by plants where they provide flavor, color, and health effects $(75,76)$, and they have attracted research attention because of their effective antioxidant effects which may prevent environmental damage (73). Table 1 shows different subtypes of flavonoids from dietary and medicinal plant sources. Flavonoids exert various pharmacological activities in mammals and have been commonly used in studies on various diseases $(99,100)$. In vivo and in vitro studies showed that these plant compounds exert beneficial effects such as antitumor, antibacterial, antiviral, liver-protective, anti-inflammatory, antipyretic, analgesic, antihypertensive, and anti-aging effects, in addition to neutralization of free radicals, improvement of immune functions, and beneficial effects on the cardiovascular system (101, 102).

Flavonoids share a particular molecular structure which is formed by the connection of two benzene rings with three carbon atoms, by which these compounds differ from other plant compounds $(99,100)$ (Figure 2). Flavonoids are assigned to six subcategories based on their structures (103). Figure 3 describes the structural characteristics and representative compounds of the six flavonoid subgroups in detail. In the following sections, we revisit epigenetic cancer effects of flavonoids including flavonols (kaempferol, myricetin, and quercetin), flavones (diosmin, apigenin, luteolin, and chrysin), isoflavones (daidzein and genistein), flavanones (naringenin, naringin, hesperidin, phlorizin, taxifolin, and silibinin), flavanols (EGCG and theaflavins), and anthocyanidins (delphinidin and pelargonidin).

\section{Flavonols}

Kaempferol

Kaempferol, a flavonol compound, is derived from Zingiberaceae plants and commonly occurs in Ardisiae Japonicae Herba, Dysosmae Verspiellis Rhixoma Et Radix, Lobeliae Chinensis Herba, strawberries, grapefruit, grapes, broccoli, and other vegetables, fruits, and teas. Its physiological functions include antioxidation, prevention of cancer, inhibition of fat formation, protection of the nervous system and the heart, and antidiabetic and anti-allergy effects (104-106). Recent studies suggested that kaempferol intake is associated with reduced cancer incidence. In a study of epithelial ovarian cancer, the population with the highest intake of kaempferol had a $40 \%$ reduction in the incidence of ovarian cancer compared with the lowest fifth (107). In a cohort study, total flavonol intake was associated
TABLE 1 | Dietary and plant sources of the different types of flavonoids.

\begin{tabular}{|c|c|c|c|}
\hline Flavonoid class & Compound name & Dietary sources & Reference \\
\hline \multirow[t]{5}{*}{ Flavones } & Apigenin & Achillea millefolium L & $(77)$ \\
\hline & Luteolin & Chrysanthemi Flos & (78) \\
\hline & Tangeretin & Citrus Reticulata & (79) \\
\hline & Diosmin & Black cardamom & (80) \\
\hline & Chrysin & Propolis & (81) \\
\hline \multirow[t]{5}{*}{ Isoflavones } & Daidzein & Soybeans & (82) \\
\hline & Daidzein & Cyathulae Radix & (83) \\
\hline & Daidzein & Sojae Semen Praeparatum & \\
\hline & Genistein & Miso & (84) \\
\hline & Genistein & Eucommiae Cortex & (83) \\
\hline \multirow[t]{14}{*}{ Flavonols } & Kaempferol & Radix Bupleuri & (83) \\
\hline & Kaempferol & Polygoni Avicularis Herba & (85) \\
\hline & Kaempferol & Hippophae Fructus & (86) \\
\hline & Kaempferol & Paeoniae Radix Alba & (83) \\
\hline & Myricetin & Mori Fructus & (87) \\
\hline & Myricetin & Hippophae Fructus & (88) \\
\hline & Myricetin & Ginkgo Folium & (89) \\
\hline & Myricetin & Red wine & (90) \\
\hline & Myricetin & Black tea & (91) \\
\hline & Quercetin & Hedyotis Diffusae Herba & (83) \\
\hline & Quercetin & Radix Bupleuri & \\
\hline & Quercetin & Toosendan Fructus & \\
\hline & Quercetin & Slicing beans & (92) \\
\hline & Quercetin & Broccoli & (93) \\
\hline \multirow[t]{5}{*}{ Flavanones } & Naringenin & Grapefruit pulp & $(94)$ \\
\hline & Naringenin & Prunus yedoensis Mats & $(95,96)$ \\
\hline & Hesperidin & Viticis Fructus & \\
\hline & Hesperidin & Asteris Radix Et Rhizoma & \\
\hline & Naringin & Grapefruit juice & \\
\hline \multirow[t]{4}{*}{ Flavanols } & EGCG & Green tea & $(97)$ \\
\hline & EGCG & Ginkgo Semen & \\
\hline & ECG & Black tea & \\
\hline & EGC & Green tea & \\
\hline \multirow[t]{5}{*}{ Anthocyanidins } & Delphinidin & blueberry & (98) \\
\hline & Delphinidin & Ephedra Herba & (83) \\
\hline & Pelargonidin & Fritillariae Thunbrgii Bulbus & \\
\hline & Pelargonidin & Hippophae Fructus & \\
\hline & Pelargonidin & Mori Cortex & \\
\hline
\end{tabular}

with reduced risk of pancreatic cancer, with kaempferol showing the highest reduction in cancer risk. In addition, total flavonol intake and kaempferol intake were negatively correlated with the risk of pancreatic cancer in smokers (108). Epidemiological investigations such as these demonstrated anticancer effects of kaempferol.

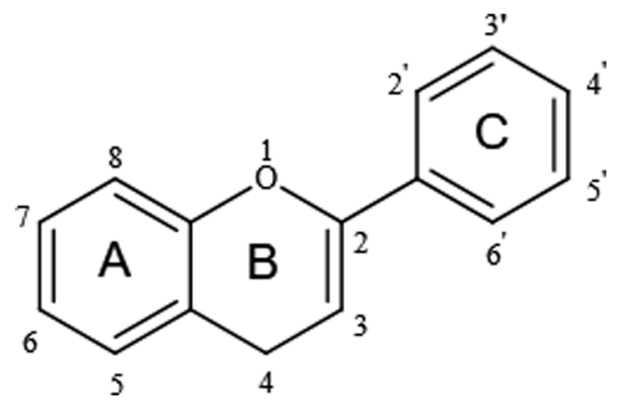

FIGURE 2 | Basic structure of flavonoids. 


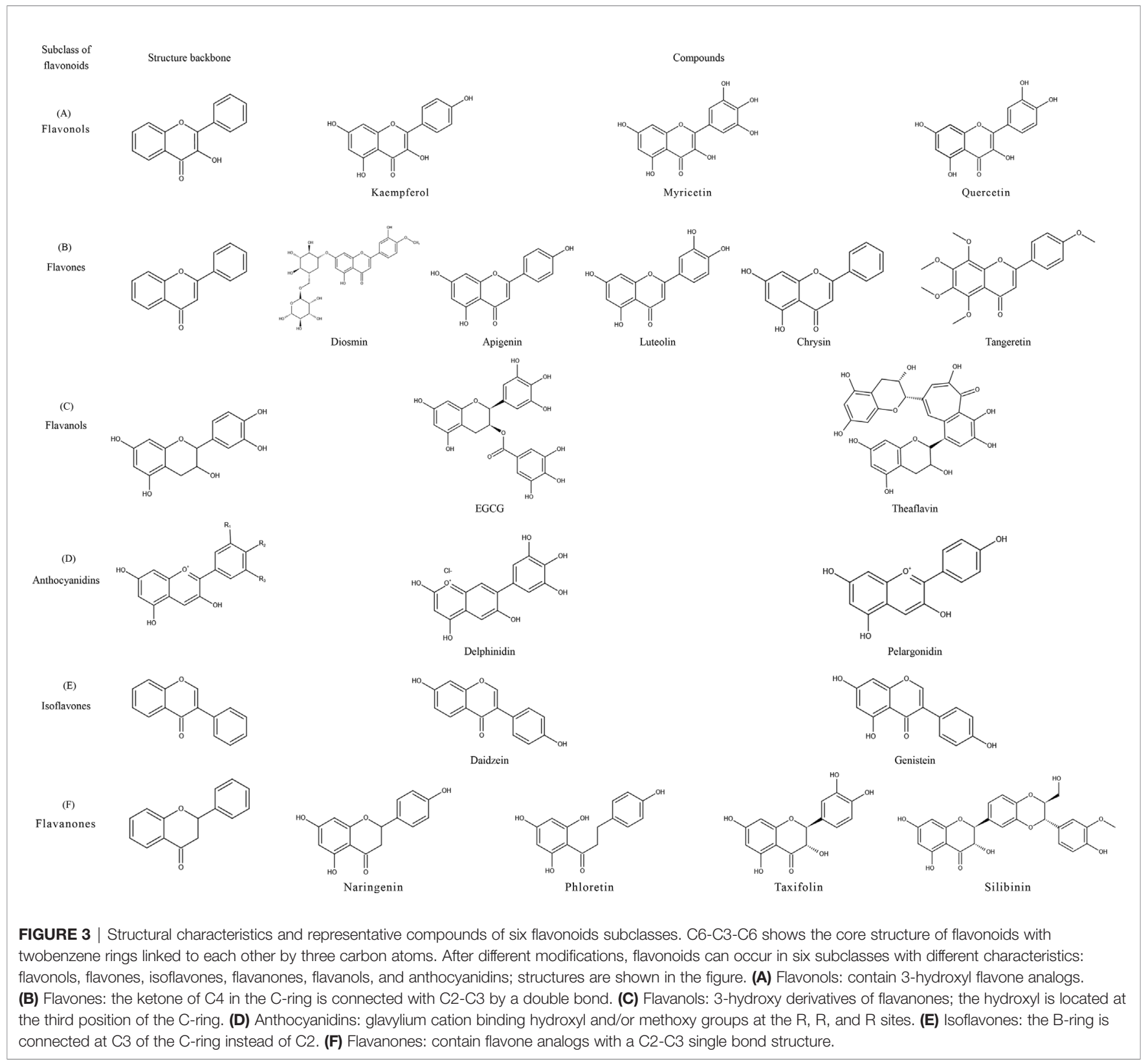

Part of the antitumor effect of kaempferol is due to its strong epigenetic effects such as targeting histone acetylation. In a previous study by Kim et al., kaempferol exerted the effect of an HDAC inhibitor (HDACi), inhibited expression of G9a, blocked the HDAC/G9a axis, and induced autophagy in gastric cancer cells (14). A different study also reported significant inhibitory effects of kaempferol on HDAC and found that kaempferol hyperacetylated histone complex $\mathrm{H} 3$ and inhibited the proliferation and survival of cancer cells in HCT-116 colon cancer cells and human hepatocellular carcinoma cell lines HepG2 and Hep3B (109).

Kaempferol is also thought to regulate DNA methylation. In HCT116, HT29, and YB5 colorectal cancer cell lines, kaempferol was found to bind to DNMT1, and it significantly downregulated
DACT2 methylation, upregulated expression of this tumor suppressor gene, blocked the $\mathrm{Wnt} / \beta$-catenin signaling pathway, and inhibited tumor cell proliferation and migration. This study also found that DACT2, regulated by kaempferol demethylation, reduced tumor load to some extent, indicating the potential of this compound for cancer therapy (110).

\section{Myricetin}

Exploring flavonols, numerous studies have shown that myricetin derived from myricanagi, Mori Fructus, ippophae Fructus, Ginkgo Folium, etc. has excellent nutritional value and biological activity, and plays a beneficial role regarding antitumor activity, prevention of cardiovascular diseases, lowering blood pressure, lowering blood lipid levels, and 
reducing complications associated with diabetes and bacteriostasis (111-114). In recent years, with the rise of epigenetic therapy, an increasing number of epigenetic effects of myricetin has been revealed.

Lee et al. observed that several bioflavonoids can inhibit epigenetic regulation of SssI DNMT and DNMT1 in a concentration-dependent manner and reduce the level of DNA methylation. Compared with fisetin and quercetin, myricetin has a more prominent inhibitory ability on the two enzymes. Myricetin $(20 \mu \mathrm{M})$ inhibited SssI DNMT-related methylation by up to $60 \%$. When mediated by COMT, the $\mathrm{IC}_{50}$ value of myricetin inhibiting methylation of DNMT1 was $1.2 \mu \mathrm{M}$ (115). This study reflects the epigenetic effects of flavonoids such as myricetin, particularly regarding inhibitory effects on DNMT.

Furthermore, epigenetic effects of myricetin nanoparticles have been reported. Silver nanoparticles(AgNPs) made from myricetin can promote oxidative stress responses and DNA damage and induce apoptosis in NIH3T3 mouse embryonic fibroblasts. Subsequent gene ontology analysis revealed that AgNPs promote nucleosome assembly and DNA methylation in the process of inducing apoptosis. A heat map showed that histones hist $2 \mathrm{~h} 2 \mathrm{ac}$ and hist1h2ah of the necroptosis pathway were significantly upregulated after treatment with AgNPs (116). This study showed that this new material plays an important role in the epigenetic regulation of apoptosis, especially at DNAmethylation and histone levels.

JMJD3, a member of the Jmj-C HDM family, is considered a key factor in inflammation and tumorigenesis. Numerous recent studies showed that myricetin exerts significant inhibitory effects on JMJD3. Mallik et al. screened eight compounds, including ZINC15271426, from 65 myricetin analogs in the ZINC database using the molecular model method. They observed excellent docking affinity (all exceeding $9.0 \mathrm{kcal} / \mathrm{mol}$ ), showing promising application prospects of these compounds as JMJD3 inhibitors (117). In addition, myricetin indirectly regulates deacetylation. Myricetin can activate HDAC SIRT1 to promote HIF- $1 \alpha$ expression and inhibit $\mathrm{cMyc}$ and $\beta$-catenin (118).

\section{Quercetin}

Quercetin occurs in Hedyotis Diffusae Herba, Radix Bupleuri, Toosendan Fructus, onions, apples, hawthorn, etc. and naturally occurs in the form of glycosides. It is a commonly used natural flavonol which can neutralize free radicals and directly inhibits tumors; furthermore, it exerts biological activities such as antiinflammatory, antibacterial, antiviral, immune-regulating, neuroprotective, anti-hypertensive, and hypolipidemic effects (119-121). Recent studies showed that quercetin modifies tumor epigenetics and can enhance the effects of epigenetic treatments when administered in combination with other drugs.

During synergistic action of quercetin and curcumin, prostate cancer cell lines PC3 and DU145 showed decreased DNMT activity and increased AR expression which induced apoptosis through the mitochondrial pathway. Compared with the singledrug group, combined administration was more effective and led to increased sensitivity of androgen-resistant prostate cancer cells to androgen receptor-induced apoptosis (122), suggesting the potential of quercetin and curcumin administration for prevention and treatment of prostate cancer.

Flavonoids quercetin and sodium butyrate can change histone acetylation modifications in cancer. Zheng et al. reported that curcumin and sodium butyrate can inhibit tumor cell growth in a dose-dependent manner. In the human esophageal cancer cell line Eca9706, both drugs can restrict cell growth, and combined administration produced stronger inhibitory effects on the proliferation of tumor cells. Western blotting showed that expression of NF- $\mathrm{KBp} 65$, HDAC1, and cyclin D1 was downregulated, whereas that of caspase-3 and p16INK $4 \alpha$ was upregulated in treatments with quercetin, sodium butyrate, or a combination thereof. The authors also observed a trend of downregulation of HDAC1-IR and upregulation in E-cadherin-IR after combined treatment (123). This study suggests that quercetin and B, particularly in combination, can regulate abnormal epigenetic changes through the HDAC1-IR-NF- $\mathrm{BB}$ signaling axis and inhibit growth of the human esophageal cancer cell line Eca9706.

Wang et al. conducted a study on increased antitumor effects of quercetin due to combined administration with arctigenin. Quercetin and/or arctigenin were used to treat prostate cancer cell lines (androgen-dependent LAPC-4 and LNCaP), and compared with the controls and single-drug treatments, combined administration enhanced the pharmacological effects on anticancer cell proliferation. Combined administration of the two drugs also inhibited expression of AR and PI3K/Akt signaling pathways and that of various cancer-related miRNAs such as miR-21, miR-19b, and miR-148a, and it exerted stronger inhibitory effects on tumor cell migration than single-drug treatments (124). The combination of these two natural compounds may provide a new approach for the treatment and prevention of prostate cancer.

Using cell experiments and xenograft models, Pham et al. found that combination of quercetin with the epigenetic drug BET inhibitor JQ1 can enhance anticancer effects on pancreatic and thyroid cancer by inhibiting tumor cell proliferation and inhibit sphere-formation ability of tumor cells, which shows the effect of targeted therapy on tumor stem cells. In addition, knocking out HnRNPA1 can enhance the inhibiting effect of JQ1 on expression of survivin and the sphere-forming ability of cancer cells, which is consistent with the effects of quercetin (125). This shows that quercetin enhances the effects of BET inhibitor JQ1 by inhibiting expression of the hnRNPA1 gene, and combined administration may have promising application prospects for cancer patients, especially regarding patients with thyroid and pancreatic cancer.

Quercetin also showed broad-spectrum epigenetic activity when used in single-drug treatments in which miRNA regulation was most prominent, as confirmed in various forms of cancer. When carcinogenicity of hexavalent chromium $\mathrm{Cr}(\mathrm{VI})$ was reduced, long-term administration of BEAS-2B human bronchial epithelial cells $\mathrm{Cr}(\mathrm{VI})$ upregulated miRNA-21, downregulated programmed cell death 4 (PDCD4), promoted ROS expression, and induced cell malignancy. This process can be inhibited by quercetin. In a nude mouse model, the tumor 
incidence in nude mice injected with $\mathrm{Cr}(\mathrm{VI})+$ quercetin BEAS$2 \mathrm{~B}$ cells was significantly lower than that in the $\mathrm{Cr}(\mathrm{VI})$ group. Furthermore, after collecting tumors from nude mice and administering quercetin, promotion of miR-21 was associated with inhibition of PDCD4 (126). These results suggest that quercetin can regulate the miRNA-21-PDCD4 axis to inhibit malignant transformation of human bronchial epithelial cells induced by $\mathrm{Cr}(\mathrm{VI})$.

Moreover, quercetin inhibits the self-renewal and proliferation of AsPC1 human pancreatic cancer cells by regulating a variety of miRNAs. After cells were treated with quercetin for $12 \mathrm{~h}$, changes in miRNA expression associated with Notch signaling and cell fate were analyzed, and 11 types of miRNAs including let-7c and miR-200b-3p were observed. miR200b-3p was further examined and was shown to be a key factor controlling cell fate. Subsequent in vitro experiments showed that miR-200b-3p enhanced by quercetin inhibited the Notch signaling pathway, adjusted the transformation of the CSC division mode from symmetry to asymmetry, inhibited selfrenewal and proliferation of CSCs, promoted cell differentiation, and reduced invasiveness (127).

Anticancer mechanisms of miRNAs regulated by quercetin have also been reported in hepatocellular carcinoma. In HepG2 hepatoma cells, quercetin promoted expression of miRNA-34a and mediated the p53/miR-34a/SIRT1 signaling mechanism to transmit apoptosis signals of cancer cells (128).

Quercetin plays a key role in inhibiting invasion and proliferation of breast cancer cells. The mechanism underlying the regulation of cancer cells is to promote expression of miR146a, activate caspase- 3 and Bax, and induce apoptosis through a mitochondrial-dependent pathway in human breast cancer cell lines MCF-7 and MDA-MB-231 to inhibit proliferation of tumor cells, inhibit expression of EGFR, and reduce invasiveness of tumor cells (129).

In osteosarcoma studies, quercetin enhanced the efficacy of cisplatin by regulating the miR-217-KRAS signaling axis. When human osteosarcoma $143 \mathrm{~B}$ cells were treated with quercetin and/or cisplatin, expression of KRAS was downregulated and miR-217 was upregulated, and a combined treatment significantly increased the expression of miRNA-217 (130). This also confirms previous reports which suggested that miR-217 targets KRAS in lung cancer cells to reverse cisplatin resistance (131).

\section{Flavones \\ Diosmin}

Diosmin is a well-known natural flavonoid used for the treatment of chronic venous insufficiency and varicose veins. Numerous recent studies showed that diosmin exerts various pharmacological activities including anti-inflammatory, antioxidative, antidiabetic, anticancer, antimicrobial, liverprotective, neuroprotective, cardiovascular-protective, kidneyprotective, and retina-protective effects $(132,133)$.

Diosmin is effective against tumors on a genetic and epigenetic level. Epigenetic intervention effects of three flavonoids and their genotoxicity and apoptosis-inducing effects were assessed in DU145 prostate cancer cells. Naringin, diosmin, and hesperidin reduced the number of cancer cells and proliferation to varying degrees, and diosmin showed the strongest gene toxicity and considerable proapoptotic activity. This study also assessed changes in global DNA methylation, and diosmin downregulated the level of 5-methyl-20-deoxycytidine in DU145 cell lines and mediated DNA demethylation to regulate the epigenome of tumor cells (134).

\section{Apigenin}

Apigenin, which is common in medicinal plants, vegetables and fruits, including Menthae Herba, Radix Salviae, Codonopsis Radix, Chrysanthemi Flos, celery, onions, and oranges, is a kind of natural flavonoids with various pharmacological activities (135-137). It has been used in studies on many diseases because of its low toxicity and strong biological effects, and it has been reported to exert substantial anti-inflammation, antioxidation, antidiabetic, antitumor, antibacterial, and antiparasitic effects. Moreover, this compound can improve the symptoms of chronic diseases, such as depression, insomnia, amnesia, and Alzheimer's disease (138-140).

Tseng et al. reported that apigenin downregulated the expression of cyclins $\mathrm{A}, \mathrm{B}$, and CDK1 in the MB-231 breast cancer cell line in a time-dependent manner, and expression of CDKI p $21^{\text {WAF1/CIP1 }}$ was also upregulated in a time-dependent manner. In addition, apigenin promotes acetylation of histone $\mathrm{H} 3$ and thus transcription of $\mathrm{p} 21^{\mathrm{WAF} 1 / \mathrm{CIP} 1}$. A nude mouse model experiment using xenotransplantation also supported this conclusion (141). This study revealed for the first time the epigenetic targeting mechanisms and effects of apigenin on breast cancer.

Paredes-Gonzalez et al. evaluated epigenetic effects of apigenin in the prevention of skin cancer. Apigenin can inhibit expression of DNMT1, 3a, 3b, and HDAC in mouse skin epidermal JB6 P+ cells, demethylate $15 \mathrm{CpG}$ sites, and silence Nrf2 to promote antioxidation and prevent skin cancer (142).

Apigenin can play the role of an HDACi in inducing apoptosis in prostate cancer cells. In prostate cancer cells and xenotransplantation models, apigenin decreases expression of apoptotic protein inhibitors such as XIAP, survivin, c-IAP1, and c-IAP2, inhibits HDAC1, upregulates acetylation of Ku70, destroys the Ku70-Bax interaction, and mediates apoptosis of prostate cancer cells by separating Bax and Ku70 (143). Similar anti-HDAC effects of apigenin were also reported by a different study on prostate cancer. Apigenin $(20-40 \mu \mathrm{M})$ inhibited HDAC activity in human prostate cancer cell lines PC-3 and 22Rv1 and reduced expression of $\mathrm{HDAC} 1$ and 3 . Histone acetylation was also increased by apigenin-mediated downregulation of HDAC, while the cell cycle regulatory protein p21/waf1 and apoptosis protein Bax were upregulated at the transcriptional level. As shown in a mouse model, bcl 2 was downregulated and Bax was upregulated in animals treated with apigenin, and growth of transplanted tumors was inhibited (144).

\section{Luteolin}

Luteolin is a natural flavone extracted from plants and is commonly found in traditional Chinese herbal medicines such 
as Lonicerae Japonicae Flos, Schizonepetae Herba, Chrysanthemi Flos and in vegetables such as broccoli, carrots, and celery. Luteolin exerts various pharmacological activities such as antiinflammatory, anti-allergy, antitumor, anti-aging, antibacterial, antiviral, heart-protective, neuroprotective, and uric acidreducing effects and is used to treat diabetes and Alzheimer's disease (145-147).

Selvi et al. confirmed that luteolin regulates epigenetics multidimensionally and inhibits growth of head and neck squamous cell carcinoma cells. Treatment of mice with luteolin inhibited p300 acetyltransferase, upregulated miR-195/215 and let7C, induced by p53, downregulated miR-135a, and significantly decreased tumor growth within four weeks (148).

Kanwal et al. found that flavonoids such as luteolin, apigenin, and chrysin can inhibit DNA methylation and trimethylation of lysine 27 on histone $\mathrm{H} 3$, and luteolin showed the strongest inhibitory effects on DNMT. Different concentrations of luteolin $(10 \mu \mathrm{M}$ and $20 \mu \mathrm{M})$ inhibited DNMT in a dosedependent manner, and molecular docking showed that luteolin can interact with DNMT residues through six hydrogen bonds. Luteolin can inhibit H3K27me3 and downregulate the expression of EZH2 in human prostate cancer DU145 cells in a concentration-dependent manner (149).

Ganai et al. found that luteolin can stably bind to class-I HDAC isomers. Luteolin, as a natural product, may have better anticancer application prospects than synthetic HDACi's which are associated with more side effects (150).

Luteolin has been reported in many studies to be a regulator of epigenetic effects in various cancer signaling pathways. Zuo et al. found that luteolin can inhibit DNMTs and HDACs in HCT116 and HT29 colon cancer cells and promote Nrf2 demethylation and upregulate its expression, which activates the Nrf2/antioxidant responsive element(ARE) pathway and inhibits cancer cell proliferation (151). Their results show that luteolin positively regulates the epigenetic effects of anticancer signaling pathways. A study on the effects of luteolin on prostate cancer cells showed that it changed the acetylation state of the gene promoter histone, downregulated expression of 22 key genes of the cell cycle pathway such as cyclin A2 and cyclin E2, and upregulated expression of cyclin-dependent kinase inhibitor 1B (152).

Luteolin also alters histone $\mathrm{H} 4$ acetylation levels and regulates estrogen levels and cell proliferation in breast cancer cells. The estrogen signal pathway gene and the cell cycle pathway gene in MCF-7 breast cancer cells are regulated by this natural compound, and PLK-1 histone $\mathrm{H} 4$ acetylation modification which regulates the cell cycle is inhibited (153). This shows that luteolin regulates gene expression through epigenetic properties involving modified histone acetylation, which is consistent with the anti-estrogenic and cell proliferation activities of luteolin.

Luteolin, a natural inhibitor of EGFR tyrosine kinase, is also used in the development of targeted therapies. Markaverich et al. found that epigenetic regulation effects of luteolin on the epidermal growth factor signaling pathway may involve upregulation of c-Fos and p21, caused by histone $\mathrm{H} 4$ binding in PC-3 human prostate cancer cells (154).

\section{Tangeretin}

Similar to naringenin and diosmin, tangeretin is a phytochemical compound derived from citrus fruits, and it shows good antifungal, anti-inflammatory, antioxidant, and anticancer effects in vivo and in vitro. Tangeretin can inhibit tumor progression through various signaling pathways and epigenetic mechanisms (155-157).

Wei et al. examined antitumor and epigenetic activities of tangeretin (PMF1) and its derivative 4'-didemethyltangeretin (PMF2). In human prostate cancer LNCaP cells, both compounds inhibited cell growth, but PMF2 exerted stronger effects and less cytotoxicity to normal cells. PMF2 also induced apoptosis by increasing expression of proapoptotic proteins Bad and $\mathrm{Bax}$, downregulating antiapoptotic proteins $\mathrm{Bcl} 2$, and activating caspase- 3 and PARP. This study also confirmed epigenetic regulation of PMF2. PMF2 can demethylate the p21 promoter and inhibit expression of DNMT3B, HDAC1, HDAC2, and HDAC4 $\backslash 5 \backslash 6$. In addition, PMF2 can interact with DNMTs in vitro, which may lead to a decrease in DNMT catalytic activity (158).

\section{Chrysin}

Chrysin is a flavonoid extracted from Artemisia mandshurica, and it is also abundant in propolis, honey, and passion fruit. It exerts a wide range of pharmacological activities such as antioxidative, antitumor, antiviral, antihypertensive, antidiabetic, antibacterial, and anti-allergy effects. Due to its wide distribution in plants and low toxicity, it has become an important substrate for drug discovery (159).

Sun et al. examined anticancer effects of chrysin extracted from Chinese propolis. When breast cancer MDA-MB-231 cells were treated with chrysin, tumor cell growth and proliferation were inhibited. In a xenotransplantation model, oral administration of chrysin to immunodeficient mice reduced the size and weight of tumors. Concurrent enzyme activity analyses showed that chrysin, an HDACi, may inhibit HDAC8 activity. This study confirmed that chrysin has anti-HDAC8 activity and can inhibit chromatin remodeling in breast cancer cells to exert anticancer effects (160). Sun et al. proposed that the anti-HDAC activity of chrysin may be related to its anticancer effects (160), which was confirmed by other experiments (161).

For instance, the anti-melanoma activity of chrysin was found to be related to its anti-HDAC activity. After melanoma A375 cells were treated with chrysin, cell proliferation was inhibited, the cell cycle was blocked at the G1 phase, HDAC-2, 3, and 8 were downregulated at the translation level, and the degree of $\mathrm{H} 3 \mathrm{me} 2 \mathrm{~K} 9$ methylation was decreased. In addition, chrysin upregulates expression of apoptosis-related protein p21 through protein methylation and hyperacetylation, which is considered an important factor leading to melanoma cell apoptosis (161).

TET1, which is involved in the demethylation of 5methylcytosine, is a promising target for gastric cancer therapy, and chrysin can promote its expression to inhibit tumor progression. In gastric cancer MKN45 cells treated with chrysin, expression of TET1 and $5 \mathrm{hmC}$ increased, and the 
increase in TET1 levels promoted apoptosis and inhibited migration and invasion of gastric cancer cells. Furthermore, a CRISPR/Cas9 system was used to knock out TET1 to promote tumor growth, which showed that TET1 expression is closely associated with tumor growth, thus chrysin is expected to become an effective target for this emerging gastric cancer (162).

\section{Isoflavones}

\section{Daidzein and Genistein}

Isoflavone is a flavonoid that mainly occurs in legumes. Due to similar characteristics regarding molecular structure and biological activities, isoflavones are also known as phytoestrogens. In addition to producing estrogens and antiestrogens, participating in lowering blood sugar, inhibiting obesity and type- 2 diabetes, controlling inflammation, and protecting nerves, isoflavones can also be used to treat tumors related to hormone disorders, cardiovascular diseases, and human reproductive functions (163-166). The representative compounds are daidzein and genistein, which are often discussed together because of their similar origin and function.

It has been reported that isoflavones are epigenetic modulators of the Wnt pathway involved in tumorigenesis and epithelial mesenchymal transformation (EMT) intervention (167-169). In a study on colon cancer, genistein affected demethylation, upregulated the Wnt antagonist gene SFRP2, and inhibited Wnt signal transduction. Methylation-specificPCR analysis showed that the demethylation degree of SFRP2 was up to $50 \%$ (168). In a different experiment involving the Wnt pathway, genistein led to demethylation of the CpG island of Wnt5a, a Wnt antagonist, and induction of re-expression of Wnt5a to inhibit proliferation of colon cancer cells (169); notably, these changes facilitated Wnt5a-associated demethylation regulation in early tumor cells, which may be a method for early intervention in colon cancer.

Epigenetic regulation of Wnt by isoflavones has also been demonstrated in vitro. Zhang et al. found that genistein included in the diet of rats can affect Wnt gene expression through DNA methylation regulation and histone modification and maintain normal Wnt signal transduction in rat colonic epithelium after exposure to the carcinogen azomethane (167), prompting the preventive effect of genistein supplementation through food intake on cancer.

The DNA methylation regulation activity of soybean isoflavones is an important mechanism for its anti-prostate cancer. Genistein and daidzein can down-regulate the methylation level of tumor suppressor gene promoter in human prostate cancer cells. When VARDI and his colleagues treated cancer cells with genistein and daidzein, EPHB2 and GSTP1 methylation was down-regulated, while BRCA1 methylation was not affected (170). Immunohistochemical results showed that the expression of BRCA1 and RASSF1A did not change, while the expression of GSTP1 and EPHB2 increased. In a different study on prostate cancer, daidzein and genistein inhibited cancer cell growth and promoted apoptosis by altering the methylation status of several genes involved in the $\mathrm{NF}-\kappa \mathrm{B}$ and p53 pathways in prostate cancer cells (171).
Genistein exerts a demethylation effect on tumor suppressor genes in esophageal squamous cell carcinoma cells. Approximately 2-20 $\mu \mathrm{mol} / \mathrm{L}$ genistein inhibited DNMT, promoted activation of $\alpha$-O6 methylguanine methyltransferase, and downregulated methylation of RAR $\beta$, p 16 INK4a and promoted their expression. Activity of DNMT was reduced in a dose-dependent manner with $20-50 \mu \mathrm{mol} / \mathrm{L}$ genistein, and HDAC activity was also inhibited by genistein $(5-100 \mu \mathrm{mol} / \mathrm{L})$ in a concentration-dependent manner. Additionally, the authors found that addition of 5-Aza-DCYD and trichostatin or SFN can enhance genistein effects through demethylation of tumor suppressor genes and inhibition of cell growth (172). However, the use of genistein alone or in combination with other drugs to reverse hypermethylation requires further research.

\section{Flavanones \\ Naringenin}

Naringenin is a common citrus flavonoid which mainly occurs in the peel of citrus fruits such as oranges, lemons, and grapefruit. It exerts pharmacological activities such as liver-protective, antioxidative, antiviral, cardiovascular-protective, kidneyprotective, antidiabetic, and anticancer effects and can be used to treat sepsis (173-175).

Curti et al. examined the regulation of miRNA (miR-17-3p and miR-25-5p) by naringenin in the process of anti-inflammation and antioxidation treatments of human colon adenocarcinoma. When Caco-2 cells were treated with racemic and enantiomeric Naringenin at subtoxic concentrations, expression of miR-17-3p and miR-25-5p decreased. The decrease of miR-17-3p is accompanied by the up-regulation of the transcription levels of two antioxidant enzymes, glutathione peroxidase 2 and manganese superoxide dismutase, which are encoded by it. however, downregulated expression of miR-25-5p was not consistent with mRNA expression of tumor necrosis factor- $\alpha$ and interleukin-6, which are pro-inflammatory cytokines and Encoded by miR-25-5p (176). These results suggest that Naringenin can achieve antioxidant activity by targeting the epigenetic mechanism of miRNAs, even though antiinflammatory effects may be mediated by other mechanisms.

\section{Hesperidin}

Hesperidin occurs in fruits of Rutaceae plants such as bergamot, orange, and lemon, and are also the important active components of some botanical drugs such as Schizonepetae Spica, Citri Fructus Retinervus, Citri Reticulatae Pericarpium Viride. Hesperidin regulate epigenetic processes and exert antiinflammatory, antioxidant, anti-obesity, and cardiovascular and anticancer effects. Hesperidin significantly reduced the growth of liver nodules in rats with liver cancer induced by diethylnitrosamine and significantly ameliorated liver histological damage. In addition, cytotoxicity of Hesperidin to HL60 cells was dose-dependent, with an $\mathrm{IC}_{50}$ of $12.5 \mathrm{mM}$, and at this concentration, it produced the maximum value of LINE-1 sequence hypomethylation (47\%). Hesperidin also downregulated methylation of ALUM2 repeats, and the highest hypomethylation level of $32 \%$ was observed at a concentration of 
$6 \mathrm{mM}$ (177). This study suggests that hesperidin, an active demethylation drug, can play a significant role in the treatment of liver cancer.

\section{Phlorizin}

Phlorizin/phloridzin is a dihydrochalcone flavonoid that mainly occurs in Rubi Fructus, and fruits, leaves, and roots of apple trees, and it has been studied for many years to examine antioxidant, anti-inflammatory, and antitumor effects on mammalian cells (178).

Sandhya et al. found that in HepG2 human liver cancer cells, MDAMB human breast cancer cells, and THP-1 leukemia cells, phlorizin and its derivatives can significantly inhibit proliferation of tumor cells, and the antiproliferative activity of fatty esters of phloridzin (a phlorizin derivative) is similar to that of sorafenib and other chemotherapeutic drugs. Furthermore, Sandhya et al. explored the antitumor mechanism of several drugs and found that fatty esters of phloridzin can inhibit DNA topoisomerase IIa activity, downregulate growth factor receptors such as the antiapoptotic genes BCL2 and PDGFR, and block the cell cycle. In addition, a variety of HDACs (HDAC1, 4, 6, 7, and 11) are downregulated by phlorizin derivatives (179). This study suggests that the chemotherapeutic effect of this phlorizin derivative may be associated with downregulation of DNA topoisomerase IIa activity, cell cycle arrest, and epigenetic activity.

\section{Taxifolin}

Taxifolin, a natural flavonoid which is common in Cinnamomi Ramulus, Fructus Ligustri Lucidi, Viticis Fructus, milk thistle, larch, and other plants, shows cardiovascular-protective, antibacterial, and free-radical scavenging effects and has shown good anticancer activity through a variety of pathways in vivo and in vitro (180, 181). For example, in breast cancer cells, taxifolin can inhibit cell proliferation and migration by downregulating $\beta$-catenin to promote EMT (182). Taxifolin has also been reported to inhibit cancer cell growth in scar cancer cells by inhibiting the PI3K/Akt/mTOR pathway (183).

Epigenetic effects of taxifolin have also been reported. After treatment with taxifolin, colony formation of mouse epidermal JB6 P+ cells was inhibited, and Nrf2, heme oxygenase-1, and NAD (P) $\mathrm{H}$ quinone oxidoreductase 1 were upregulated at transcriptional and translational levels. Bisulfite genome sequencing showed that methylation levels of the Nrf2 promoter were decreased by taxifolin, and expression of DNMT and DHAC were also reduced by taxifolin (184). This suggests that taxifolin can play a role in chemoprevention by promoting the expression of Nrf2 through an epigenetic pathway.

\section{Silibinin}

Silibinin, a representative flavanone compound, is a bioactive substance extracted from dried fruit of thistle which belongs to the family Compositae. It shows strong antioxidant functions and liver-protective, free-radical scavenging, and anti-aging, effects, among others, and it is commonly used in medicine, health care, food, and other applications.

Silibinin exerts considerable epigenetic effects and can be administered in combination with other epigenetic drugs.
Mateen et al. reported that silibinin combined with an HDACi modified epigenetics and inhibited growth of non-small cell lung cancer. In vitro experiments showed that after administration of silibinin to tumor cells, acetylation of histones $\mathrm{H} 3$ and $\mathrm{H} 4$ was upregulated, accompanied by a decrease in HDAC activity, and expression of HDAC1, 2, and 3 were downregulated. After using several HDACi's and silibinin in combination, p21 acetylation was upregulated, cytotoxicity was increased, and cell cycle arrest and apoptosis were induced (185). In vivo experiments also revealed similar epigenetic effects of silibinin, and growth of transplanted tumors was inhibited. Similarly, in a different study on non-small cell lung cancer, silibinin combined with an HDACi or DNMTi restored E-cadherin expression and reduced tumor cell migration and invasion (186).

A previous study claimed that silibinin exerts substantial preclinical anticancer activity and that it is an epigenetic regulator of prostate cancer. When human prostate cancer cell lines DU145 and PC3 were treated with silibinin, expression of EZH2, SUZ12, and EED was downregulated, accompanied by an upregulation of H3K27me3 methylation. In addition, silibinin increased the activity of DNMT and suppressed the expression of HDAC1-2 (187). Silibinin also played an epigenetic targeting role in the process of antiproliferation of bladder cancer. Silibinin showed considerable cytotoxicity to bladder cancer cells with different TP53 statuses. In the highest grade tumors (TP53 mutation status is level 3), silibinin induces global DNA hypomethylation. In low-grade tumor cells (wild type TP53 gene), silibinin downregulated expression of HDAC and HAT (188).

Like many flavonoids, silibinin also regulates noncoding RNAs. In the exploration of anti-breast cancer, Silibinin has been found to induce apoptosis by regulating microRNA. When MCF-7 cells were treated with silibinin, decreased expression of miR-21 and miR-155 was detected, and apoptosis occurred in a dose- and time-dependent manner. Shengxin analysis was used to predict the potential targets of two kinds of microRNAs, caspase- 9 and bid. PCR results showed that expression of caspase- 9 and bid were increased, which was consistent with the results of the dry and wet experiments (189).

\section{Flavanols EGCG}

Tea is the second most commonly consumed beverage in the world after water and is particularly common in Asia. Catechins are flavanols, and they are the main functional components of tea, comprising various monomer structures among which EGCG is most prominent due to its regulatory effects on many aspects of human physiological and pathological processes. EGCG has neurotrophic, anticancer, and antifibrotic pharmacological activities and plays an important role in inhibiting oxidation and inflammation (190-192). Epigenetic regulation of cancer by EGCG alone or in combination with other compounds was described in many recent studies.

Sheng et al. examined methylation regulation of EGCG in breast cancer. The tumor suppressor gene SCUBE2 is frequently methylated and silenced in breast cancer, while EGCG has been reported to regulate the levels of methylation in the promoter region of various tumor-related genes. In this study, MDA-MB- 
231 and MCF-7 cell lines were treated with EGCG, and an MTT assay showed that growth of breast cancer cells was inhibited and the cell viability was significantly decreased; migration and invasion abilities of breast cancer cells were also inhibited. Regarding the underlying mechanism, EGCG reactivated SCUBE2 gene expression. Real-time PCR revealed that transcription of DNMT1, DNMT3a, and DNMT3b was downregulated, and the degree of DNA methylation was also reduced (15).

EGCG has been reported to reverse both DNA methylation and histone acetylation abnormalities to induce apoptosis in breast cancer cells and inhibit cancer development. When EGCG and sulforaphane (SFN) were used in a breast cancertransformed cell system, cell viability decreased and apoptosis and cell cycle arrest were induced. EGCG decreased the activities of DNMT1 and HDAC1, and combined administration was more effective in regulating epigenetics. To further explore the regulation of epigenetic aberrations, histone $\mathrm{H} 3$ acetylation and DNA methylation levels were examined, and cotreatment with EGCG and SFN significantly promoted global acetylation of histone $\mathrm{H3}$ in the breast cancer-transformed cell system. Cluster analysis and screening of methylation status using probes showed that the methylation status of tumor-related genes was changed to varying degrees. In addition, combined treatment inhibited oncogene Septin9 and promoted expression of the tumor suppressor gene DCBLD2. EGCG and/or SFN inhibited xenograft tumor growth in breast cancer mice, and the combined effect of the two drugs was stronger (193). This new dietary combination shows promising prospects for the prevention and treatment of breast cancer.

Deb et al. conducted experiments and proposed that green tea polyphenol (GTP) and its main active ingredient EGCG can remedy epigenetic disorders caused by abnormal expression of matrix metalloproteinase-3 (TIMP-3) in prostate cancer. GTP/ EGCG decreased invasiveness and migration of prostate cancer cells and decreased the activity of matrix metalloproteinases (MMPs) such as MMP-2 and MMP-9. TIMP-3 was upregulated at a transcriptional and translational level, whereas acetylation of class-I HDAC, EZH2, and H3K9/18 and H3K27 trimethylation were downregulated; low expression of class-I HDAC and EZH2 was due to activation of TIMP-3. Deb et al. then used clinical samples for verification. After analyzing data of patients treated with EGCG, they found decreased expression of MMP-2, MMP-9, class-I HDAC, and EZH2, and TIMP-3 was upregulated, which was consistent with experimental results at a cellular level (16).

Zhao et al. reported that EGCG can regulate lncRNAs and miRNAs to reverse gastric cancer. When gastric cancer AGS and SGC7901 cell lines were treated with different doses of EGCG, growth of tumor cells was inhibited in a time- and dose-dependent manner. Bioinformatics showed that EGCG altered gene expression in gastric cancer cells and participated in the regulation of cell metastasis. Expression of LINC00511, which promotes tumor metastasis and proliferation, can be downregulated by EGCG, and miR-29b, as a downstream target of LINC00511, can be inhibited by this lncRNA, thus increasing expression of carcinogenesis-related
KDM2A (a kind of KDM) (17). This study reflects epigenetic effects of EGCG on proliferation, metastasis, and invasion of gastric cancer, particularly regarding targeting of the LINC00511/miR-29b/ KDM2A axis.

Multilevel epigenetic effects of EGCG on hematological tumors have also been examined. During acute promyelocytic leukemia (APL), GTP has been shown to inhibit cell proliferation and cause tumor cell apoptosis. Borutinskaite et al. proposed that during the antitumor process, EGCG regulates expression of cell cycle-related genes, promotes expression of transcriptional regulatory protein families $\mathrm{C} / \mathrm{EBP} \alpha$ and $\mathrm{C} / \mathrm{EBP} \epsilon$, and upregulates PCAF and p27. RT-qPCR results showed that DNMT1, HDAC1, and HDAC2 were inhibited by EGCG, and G9A, which is related to $\mathrm{H} 3 \mathrm{~K} 9 \mathrm{me} 2$ methylation, was also downregulated. Expression of genes related to PRC2 with HMT activity was inhibited at the protein level, and the binding effect of these genes with acetylated histone $\mathrm{H} 4$ and acetylated H3K14 is reduced, while in cell cycle-related genes such as $\mathrm{C} / \mathrm{EBP} \alpha$ and acetylated $\mathrm{H} 3 \mathrm{~K} 14$, the relationship between H4 and H4 has become closer (194). EGCG is not only used as a cell cycle blocker but also has an epigenetic remedy, and it has considerable potential for application in the treatment of APL.

\section{Theaflavins}

EGCG is a representative biologically active constituent of green tea, and theaflavins are natural flavonoids which are highly abundant in black tea where they are responsible for color and taste; moreover, these compounds are considered effective antioxidant and anticancer agents (195-197).In an enzyme inhibition test, theaflavins were identified as natural DNMT inhibitors. it inhibits DNMT1 by $65 \%$, and the $\mathrm{IC}_{50}$ value of DNMT1 inhibition was $85.33 \mu \mathrm{M}$ (198).

A different study found that theaflavins can reduce the activity of DNMT1 and DNMT3a and inhibit the proliferation of colon cancer cells HCT-116 and the progression of solid tumors induced by EAC in mice. The authors found that theaflavins can downregulate the activity of DNMT, both in vivo and in vitro. In addition, immunohistochemical analysis of mouse tumor tissues showed that theaflavins inhibited the expression of DNMT (199). This study demonstrates that theaflavins act as potential DNMT inhibitors in colorectal cancer.

\section{Anthocyanidins}

Anthocyanidins are natural water-soluble pigments belonging to the group of flavonols which are commonly found in plant petals and fruits. Because of their active biological activity and coloring function, they are commonly used in the production of food, drinks, and medicine. These flavonoids exert beneficial functions including vision-protective, antioxidative, antitumor, and anticardiovascular disease effects, and they can be used for preventing and treating type- 2 diabetes and treating obesity (200-202). Due to the similarity of source and structure, different types of anthocyanidins show similar epigenetic effects in function.

In a report on the prevention of skin cancer, anthocyanidins were shown to modulate epigenetic activation of the NRF2-ARE 
pathway and inhibit carcinogenesis in JB6 P+ cells. Kuo et al. treated JB6 P+ cells with the anthocyanidin delphinidin and found that ARE-driven luciferase activity was markedly upregulated, Nrf2 and its downstream antioxidant and carcinogenic detoxion-related genes were upregulated, and Nrf2-ARE was activated. Kuo et al. further investigated epigenetic activity of anthocyanidins during skin cancer. Delphinidin not only demethylates the Nrf2 promoter, but also inhibits expression of DNMTs and HDACs (203).

A different study on skin cancer study discussed the epigenetic regulation of Nrf2-ARE by pelargonidin, which is a commonly studied anthocyanidin. Similar to delphinidin, pelargonidin promoted activation of the Nrf2-ARE signaling pathway, upregulated expression of the Nrf2 target gene, demethylated the Nrf2 promoter at an epigenetic level, and inhibited expression of DNMT and HDAC (204).

The activity of anthocyanidins that target miRNAs has also been examined. Black raspberry anthocyanins (BRB) inhibit growth of human colon cancer cells by upregulating miR-24-1$5 p$. BRB upregulated the expression of miR-24-1-5p in a human colorectal cancer cell line and downregulated $\beta$-catenin in an AOM/DSS-induced mouse model. In addition, the authors used bioinformatics to predict $\beta$-catenin as a target gene of miR-24-1$5 \mathrm{p}$ and confirmed this using RT-qPCR and western blotting. The results showed that miR-24-1-5p inhibited the expression of $\beta$ catenin. In cell experiments, miR-24-1-5p regulated the downstream target genes of the $\mathrm{Wnt} / \beta$-catenin signaling pathway, and cyclinD1, c-Myc, and CDK4 were downregulated at the transcriptional and translational level (205). This study suggests that miR-24-1-5p may act as a regulator of the $\mathrm{Wnt} / \beta$ catenin signaling pathway to inhibit colorectal cancer, which is one of the possible mechanisms of anthocyanin anticancer effects through epigenetic pathways.

\section{DISCUSSION}

\section{Epigenetics as a Link Between Flavonoids and Prevention and Treatment of Cancer}

The epigenetic genome is affected by acquired factors, and natural compounds consumed by dietary and medicinal plants are involved in shaping the dynamic balance of epigenetic state $(206,207)$ (Figure 4). Natural compounds derived from natural medicines and foods which may act as epigenetic regulators to remedy adverse gene expression patterns have been accepted by the scientific community. Flavonoids are indispensable compounds in in human body, and their epigenetic effects may help counteract a variety of diseases.

Flavonoids show activity against various modifications in the multilevel epigenetic interaction network of cancer, from DNA histones to noncoding RNAs. Specifically, one kind of flavonoids can be involved in the remodeling of a variety of related enzymes or non-coding RNA in modifying one level of cancer epigenetic regulation. Also, one flavonoid compound can modify multilevel epigenetic network, playing a role in regulating DNA methylation, histone modification and regulating non-coding $\mathrm{RNA}$, and at the same time up-regulate tumor suppressor genes and down-regulate oncogenes to interfere with the occurrence and progression of cancer (Figure 1). Remodeling of these epigenetic links eventually leads to the accumulation of changes in cell metabolism and self-renewal and ultimately results in the loss of tumor cell carcinogenicity (208-210).

Considering the heterogeneity of the population and the multi-target complexity of the epigenetic modification network, population-based clinical trials and observational studies have not yet shown sufficient clear links for flavonoids to target epigenetics. However, the success of in vivo and in vitro studies has fully demonstrated the driving force of flavonoids on epigenetics and has shown considerable therapeutic effects on different cancers (Table 2). This also encourages people to design more feasible solutions to search for the chain of evidence that these phytochemicals is effective in maintaining the human body's epigenetic balance and disease prevention.

\section{Current Challenges for Flavonoid-Targeted Epigenetic Antitumor Research and Development}

Research on flavonoids is inspired by their biological effects, including, but not limited to, antioxidation, free-radical scavenging, cell cycle regulation, anti-estrogens affects, protein tyrosine kinase inhibition, and epigenetic activity (211-214). Plant compounds may exert a plethora of effects (215), which

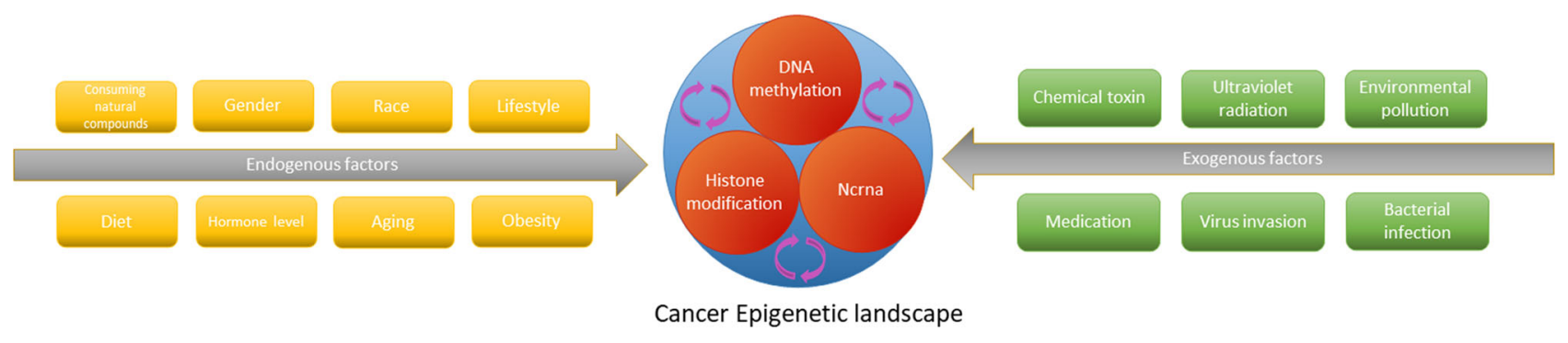

FIGURE 4 | The epigenetic cascade network mediated by endogenous and exogenous factors interferes with tumorigenesis and progression by affecting gene expression. 
TABLE 2 | Epigenetic effects of flavonoids on different types of cancers in vitro and in vivo.

\begin{tabular}{|c|c|c|c|c|c|c|c|c|c|}
\hline $\begin{array}{l}\text { Flavonoid } \\
\text { subtype }\end{array}$ & Phytochemical & $\begin{array}{c}\text { Epigenetic } \\
\text { modifications }\end{array}$ & Molecular targets & $\begin{array}{l}\text { Regulation of cell } \\
\text { phenotypes }\end{array}$ & Dose & In vitro model & In vivo model & Cancer species & References \\
\hline \multirow[t]{8}{*}{ Flavonols } & Kaempferol & $\begin{array}{l}\text { HDAC inhibitor } \\
\text { G9a inhibitor }\end{array}$ & $\begin{array}{l}\text { Down-regulation of P62; } \\
\text { Up-regulation of p-JNK and } \\
\text { CHOP }\end{array}$ & $\uparrow$ Autophagy & $25,50,100 \mu \mathrm{M}$ & $\begin{array}{l}\text { AGS, SNU- } \\
216, \text { NCI-N87, } \\
\text { SNU-638, and } \\
\text { MKN-74 cell } \\
\text { lines }\end{array}$ & & Gastric cancer & (14) \\
\hline & Kaempferol & HDAC inhibitor & & $\begin{array}{l}\downarrow \text { Cell viability } \\
\downarrow \text { proliferation }\end{array}$ & $5-100 \mu \mathrm{M}$ & $\begin{array}{l}\text { Hepg2,Hep3B } \\
\text { cells }\end{array}$ & & Liver cancer & (109) \\
\hline & Kaempferol & HDAC inhibitor & & $\begin{array}{l}\downarrow \text { Cell viability } \\
\downarrow \text { proliferation }\end{array}$ & $5-100 \mu \mathrm{M}$ & HCT -116 cells & & Colon cancer & (109) \\
\hline & Kaempferol & $\begin{array}{l}\text { DNMT1 inhibitor } \\
\text { DNMT3b inhibitor } \\
\text { DNMT3a inhibitor }\end{array}$ & $\begin{array}{l}\text { Down-regulation of DACT2 and } \\
\beta \text {-catenin }\end{array}$ & $\begin{array}{l}\downarrow \text { Proliferation } \\
\downarrow \text { Migration }\end{array}$ & $\begin{array}{c}1.25-150 \mu \mathrm{M} ; \\
75 \text { and } 150 \mathrm{mg} / \mathrm{kg}\end{array}$ & $\begin{array}{l}\text { HCT116,HT29 } \\
\text { and YB5 cell } \\
\text { lines }\end{array}$ & Nude mice & Colorectal cancer & (110) \\
\hline & Quercetin & $\begin{array}{l}\text { Promotion of mir-146a } \\
\text { expression }\end{array}$ & $\begin{array}{l}\text { Activation of caspase- } 3 \text { and Bax; } \\
\text { Inhibition of EGFR expression }\end{array}$ & $\begin{array}{l}\uparrow \text { Apoptosis } \\
\downarrow \text { Proliferation } \\
\downarrow \text { Invasiveness of } \\
\text { tumor cells }\end{array}$ & $\begin{array}{c}0,25,50,80 \text { and } 100 \\
\mu \mathrm{m} / \mathrm{ml} \\
10 \mathrm{mg} / \mathrm{kg}\end{array}$ & $\begin{array}{l}\text { MCF-7 and } \\
\text { MDA-MB-231 } \\
\text { cells }\end{array}$ & $\begin{array}{l}\text { Athymic nude } \\
\text { mice }\end{array}$ & Breast cancer & (129) \\
\hline & Quercetin & $\begin{array}{l}\text { Promotion of mir- } 217 \\
\text { expression }\end{array}$ & Down-regulation of kras & $\downarrow$ Viability & $\begin{array}{c}0,5,10,50, \text { and } 100 \\
\mu \mathrm{M}\end{array}$ & 143B cells & & Osteosarcoma & (130) \\
\hline & Quercetin & $\begin{array}{l}\text { Promotion of mir-200b- } \\
3 p \text { expression }\end{array}$ & $\begin{array}{l}\text { Down-regulation of Notch } \\
\text { signaling pathway }\end{array}$ & $\begin{array}{l}\uparrow \text { Asymmetric cell } \\
\text { division } \\
\downarrow \text { Self-renewal } \\
\downarrow \text { Proliferation }\end{array}$ & $50 \mu \mathrm{m}$ & $\begin{array}{l}\text { Aspc1 and } \\
\text { PANC1 cells }\end{array}$ & & Pancreatic cancer & $(127)$ \\
\hline & Quercetin & $\begin{array}{l}\text { Promotion of mir-34a } \\
\text { expression }\end{array}$ & $\begin{array}{l}\text { Down-regulation of SIRT1; } \\
\text { Up-regulation of p53 and p21 }\end{array}$ & $\begin{array}{l}\uparrow \text { Apoptosis } \\
\text { \Proliferation }\end{array}$ & $31.25 \mu \mathrm{M}$ & Hepg2 cells & & Liver cancer & (128) \\
\hline \multirow[t]{6}{*}{ Flavones } & Diosmin & DNA hypermethylation & & $\begin{array}{l}\uparrow \text { Apoptosis } \\
\text { \Proliferation }\end{array}$ & $\begin{array}{c}0,50,100,150,200 \text { and } \\
250 \mu \mathrm{M}\end{array}$ & DU145 cells & & Prostate cancer & (134) \\
\hline & Apigenin & HDAC inhibitor & $\begin{array}{l}\text { Down-regulation of cyclin } \mathrm{A}, \mathrm{B} \\
\text { and CDK1; } \\
\text { Up-regulation of } \mathrm{p} 21^{\text {waf1/CIP1 }}\end{array}$ & $\begin{array}{l}\downarrow \text { Proliferation } \\
\downarrow \text { Cell cycle arrest }\end{array}$ & $\begin{array}{c}0,10 \\
20 \text { and } 40 \mu \mathrm{M}\end{array}$ & $\begin{array}{l}\text { MDA-MB-231 } \\
\text { cells }\end{array}$ & $\begin{array}{l}\text { Athymic nude } \\
\text { mice }\end{array}$ & Breast cancer & (141) \\
\hline & Apigenin & HDAC inhibitor & $\begin{array}{l}\text { Decrease the expression of XIAP, } \\
\text { survivin, c-IAP1 and c-IAP2; } \\
\text { Disruption of Ku70-Bax } \\
\text { interaction }\end{array}$ & $\begin{array}{l}\uparrow \text { Apoptosis } \\
\uparrow \text { Cell cycle block } \\
\downarrow \text { Cell survival rate }\end{array}$ & $\begin{array}{l}5-40 \mu \mathrm{M} \\
20,50 \mu \mathrm{g}\end{array}$ & $\begin{array}{l}\text { PC-3 } \\
\text { And DU145 } \\
\text { cells }\end{array}$ & $\begin{array}{l}\text { Athymic nude } \\
\text { mice }\end{array}$ & Prostate cancer & (143) \\
\hline & Apigenin & $\begin{array}{l}\text { HDAC1 inhibitor } \\
\text { HDAC3 inhibitor }\end{array}$ & $\begin{array}{l}\text { Up-regulation of } \mathrm{p} 21^{\text {waf1/CIP1 }} \text { and } \\
\text { bax in transcriptional levels }\end{array}$ & $\begin{array}{l}\uparrow \text { Growth Arrest } \\
\uparrow \text { Apoptosis }\end{array}$ & $\begin{array}{c}20-40 \mu \mathrm{M} \\
20 \text { and } 50 \mu \mathrm{g}\end{array}$ & $\begin{array}{l}\mathrm{PC}-3 \text { and } \\
22 \mathrm{Rv} 1 \text { cells }\end{array}$ & $\begin{array}{l}\text { Athymic nude } \\
\text { mice }\end{array}$ & Prostate cancer & (144) \\
\hline & Luteolin & $\begin{array}{l}\text { Inhibition of p300 } \\
\text { acetyltransferase and } \\
\text { histone acetylation; } \\
\text { Up-regulation of mir-195/ } \\
\text { 215,let7c; } \\
\text { Down-regulation of mir- } \\
\text { 135a }\end{array}$ & $\begin{array}{l}\text { Up-regulation of POFUT and } \\
\text { DICER; } \\
\text { Down-regulation of E2F2,DOK2 }\end{array}$ & $\begin{array}{l}\uparrow \text { Cell cycle arrest } \\
\downarrow \text { Cell migration }\end{array}$ & $\begin{array}{c}10 \mu \mathrm{M} \text { and } 25 \mu \mathrm{M} \\
100 \mathrm{mg} / \mathrm{kg}\end{array}$ & $\mathrm{KB}$ cells & Xenograft mice & $\begin{array}{l}\text { Head and neck } \\
\text { squamous cell } \\
\text { carcinoma }\end{array}$ & (148) \\
\hline & Luteolin & $\begin{array}{l}\text { DNMT inhibitor } \\
\text { HMT inhibitor } \\
\text { Down-regulation of EZH2 }\end{array}$ & & & $10-\mu \mathrm{M}, 20-\mu \mathrm{M}$ & DU145 cells & & Prostate cancer & (149) \\
\hline
\end{tabular}




\begin{tabular}{|c|c|c|c|c|c|c|c|c|c|}
\hline $\begin{array}{l}\text { Flavonoid } \\
\text { subtype }\end{array}$ & Phytochemical & $\begin{array}{c}\text { Epigenetic } \\
\text { modifications }\end{array}$ & Molecular targets & $\begin{array}{l}\text { Regulation of cell } \\
\text { phenotypes }\end{array}$ & Dose & In vitro model & In vivo model & Cancer species & References \\
\hline & Luteolin & $\begin{array}{l}\text { DNMT inhibitor } \\
\text { HDAC inhibitor }\end{array}$ & $\begin{array}{l}\text { Up-regulation of Nrf2,HO-1, and } \\
\text { NQO1 expression }\end{array}$ & $\begin{array}{l}\downarrow \text { Cell proliferation } \\
\downarrow \text { Cellular } \\
\text { transformation }\end{array}$ & 10- $\mu \mathrm{M}$ and $20-\mu \mathrm{M}$ & $\begin{array}{l}\text { HCT116 } \\
\text { And HT29 }\end{array}$ & & Colon cancer & (151) \\
\hline & Chrysin & HDAC8 inhibitor & Promoting p21 expression & $\begin{array}{l}\downarrow \text { Cell growth } \\
\uparrow \text { Cell differentiation }\end{array}$ & $\begin{array}{c}10,20 \text {, and } 40 \mu \mathrm{M} ; \\
45 \text { or } 90 \mathrm{mg} / \mathrm{kg}\end{array}$ & $\begin{array}{l}\text { MDA-MB-231 } \\
\text { cells }\end{array}$ & Nude mice & Breast cancer & $(160)$ \\
\hline & Chrysin & HDAC2,3,8 inhibitor & $\begin{array}{l}\text { Promoting STAT-1 and p21 } \\
\text { expression }\end{array}$ & $\begin{array}{l}\downarrow \text { Cell proliferation } \\
\uparrow \text { Cell cycle }\end{array}$ & $40,120 \mu \mathrm{M}$ & A375 cells & & Melanoma & $(161)$ \\
\hline & Chrysin & $\begin{array}{l}\text { Increase the expression } \\
\text { of TET1 and } 5 \mathrm{hmc}\end{array}$ & $\begin{array}{l}\text { Promoting the expression of BAX } \\
\text { and inhibiting the expression of } \\
\text { bcl2 }\end{array}$ & $\begin{array}{l}\uparrow \text { Apoptosis } \\
\downarrow \text { Cancer cell } \\
\text { migration and } \\
\text { invasion }\end{array}$ & $\begin{array}{c}0,10,20,40,80,160 \\
\mu \mathrm{M} ; \\
20 \mathrm{mg} / \mathrm{kg}\end{array}$ & MKN45 cells & $\begin{array}{l}\text { Nude Mice } \\
\text { Xenograft Model }\end{array}$ & Gastric cancer & (162) \\
\hline \multirow[t]{4}{*}{ Isoflavones } & Genistein & Demethylation & $\begin{array}{l}\text { Up-regulation of SFRP2, inhibition } \\
\text { of Wnt signal transduction; } \\
\text { Decreasing nuclear } \beta \text {-catenin and } \\
\text { increasing phospho- } \beta \text {-catenin } \\
\text { accumulation }\end{array}$ & $\begin{array}{l}\downarrow \text { Cell viability } \\
\downarrow \text { Proliferation } \\
\uparrow \text { Apoptosis }\end{array}$ & $75 \mathrm{mmol} / \mathrm{L}$ & DLD-1 cells & & Colon cancer & (168) \\
\hline & Genistein & $\begin{array}{l}\text { Decreasing of DNA } \\
\text { methylation level }\end{array}$ & Up-regulation of WNT5a & $\downarrow$ Cell proliferation & $75 \mu \mathrm{mol} / \mathrm{l}$ & SW1116 cells & & Colon Cancer & (169) \\
\hline & Genistein & $\begin{array}{l}\text { DNA methylation } \\
\text { regulation and histone } \\
\text { modification }\end{array}$ & $\begin{array}{l}\text { Down-regulation of Sfrp2,Sfrp5 } \\
\text { and Wnt5a }\end{array}$ & & $140 \mathrm{mg} / \mathrm{kg}$ & & $\begin{array}{l}\text { Timed-pregnant } \\
\text { Sprague-Dawley } \\
\text { rats }\end{array}$ & Colon cancer & $(167)$ \\
\hline & Genistein & DNMT inhibitor & $\begin{array}{l}\text { Up-regulation of RAR } \beta \\
\text { And p16INK4a }\end{array}$ & $\downarrow$ Cell growth & $2-100 \mu \mathrm{mol} / \mathrm{L}$ & $\begin{array}{l}\text { KYSE } \\
510, \text { KYSE } \\
150 \text { cell lines }\end{array}$ & & $\begin{array}{l}\text { Esopharachaquest } \\
\text { cell carcinoma }\end{array}$ & (172) \\
\hline \multirow[t]{4}{*}{ Flavanones } & Hesperidin & Hypomethylation & & $\downarrow$ Cell viability & $\begin{array}{c}0.78 \text { to } \\
25 \mathrm{~mm} ; 250,500,1000 \\
\text { ppm }\end{array}$ & $\begin{array}{l}\text { HL60 } \\
\text { Cell line }\end{array}$ & $\begin{array}{l}\text { Pathogen-free } \\
\text { male Sprague- } \\
\text { Dawley rats }\end{array}$ & Liver cancer & $(177)$ \\
\hline & Silibinin & HDAC1,2,3 inhibitor & & $\begin{array}{l}\downarrow \text { Migration } \\
\downarrow \text { Invasion }\end{array}$ & $3.75-12.5 \mu \mathrm{M}$ & H1299 cells & & $\begin{array}{l}\text { Non-small cell lung } \\
\text { cancer }\end{array}$ & (186) \\
\hline & Silibinin & $\begin{array}{l}\text { Improvement of total } \\
\text { DNMT activity; } \\
\text { Inhibition of the activity of } \\
\text { HDAC1, } 2\end{array}$ & $\begin{array}{l}\text { Down-regulation of EZH2,SUZ12 } \\
\text { and EED }\end{array}$ & & $25-75 \mu \mathrm{g} / \mathrm{ml}$ & $\begin{array}{l}\text { DU145 and } \\
\text { PC3 cell lines }\end{array}$ & & Prostate cancer & $(187)$ \\
\hline & Silibinin & $\begin{array}{l}\text { Down-regulation of mir- } \\
21 \text { and mir-155 }\end{array}$ & $\begin{array}{l}\text { Up-regulation of caspase- } 9 \text { and } \\
\text { bid }\end{array}$ & $\begin{array}{l}\downarrow \text { Proliferation } \\
\uparrow \text { Apoptosis }\end{array}$ & $0-300 \mu \mathrm{M}$ & MCF-7 cells & & Breast cancer & (189) \\
\hline \multirow[t]{3}{*}{ Flavanols } & EGCG & $\begin{array}{l}\text { DNMT1 inhibitor } \\
\text { DNMT3a inhibitor } \\
\text { DNMT3b inhibitor }\end{array}$ & Up-regulation of SCUBE2 & $\begin{array}{l}\downarrow \text { Cell growth } \\
\downarrow \text { Migration and } \\
\text { invasion }\end{array}$ & $0-100 \mu \mathrm{M}$ & $\begin{array}{l}\text { MDA-MB-231 } \\
\text { and MCF-7 cell } \\
\text { lines }\end{array}$ & & Breast cancer & (15) \\
\hline & EGCG & $\begin{array}{l}\text { Regulation of } \\
\text { LINC00511/mir-29b/ } \\
\text { KDM2A axis }\end{array}$ & & $\begin{array}{l}\downarrow \text { Proliferation } \\
\downarrow \text { Metastasis } \\
\downarrow \text { Invasion }\end{array}$ & $0-100 \mu \mathrm{M}$ & $\begin{array}{l}\text { AGS and } \\
\text { SGC7901 cell } \\
\text { lines }\end{array}$ & & Gastric cancer & $(17)$ \\
\hline & EGCG & $\begin{array}{l}\text { DNMT1 inhibitor } \\
\text { HDAC1 inhibitor } \\
\text { HDAC2 inhibitor } \\
\text { G9a inhibitor }\end{array}$ & $\begin{array}{l}\text { Up-regulation of C/EBP } \alpha, \mathrm{C} / \mathrm{EBP} \epsilon \text {, } \\
\mathrm{PCAF} \text { and } 27\end{array}$ & $\begin{array}{l}\downarrow \text { Proliferation } \\
\uparrow \text { Apoptosis }\end{array}$ & $30,40 \mu \mathrm{M}$ & $\begin{array}{l}\text { NB4 and HL- } \\
60 \text { cells }\end{array}$ & & APL & (194) \\
\hline
\end{tabular}


may, however, harbor some disadvantages $(216,217)$. Flavonoids produce anticancer effects through various mechanisms, and unspecific action may be problematic for potential drug administration. This is also a clinically important consideration regarding the use of phytochemicals $(213,218)$. In addition, the hierarchical interaction and reversibility of the epigenetic network suggests that when flavonoids modulate epigenetic modifications in multiple dimensions, they may cause deviations in efficacy and expected results, This is also a problem faced by other epigenetic drugs in the application $(219,220)$. However, based on a large number of experimental studies, we believe that flavonoids have beneficial preclinical benefits of regulating cancer epigenetics. Their broad biological activities, however, should not be a reason to dismiss flavonoids from disease research and treatment; instead, the underlying mechanisms warrant further research to exploit the inherent therapeutic potential.

Even though clinical flavonoid research focusing on tumor epigenetics has made considerable progress recently, current evidence for clinical application is still insufficient (218). A series of problems such as insufficient bioavailability currently prevent clinical application of various plant products including flavonoids. Fortunately, the academic community has begun to tackle this problem and has provided effective solutions such as combined administration with other plant compounds or anticancer drugs to improve anticancer efficacy and nano-drug carrier system to improve the pharmacokinetic characteristics of flavonoids. In addition, considering that dosages used in cell culture and animal models may not be physiological and may thus not be transferable to humans, determining the most effective dosage of flavonoids is a crucial part of basic and clinical research to effectively and safely exploit epigenetic antitumor effects of flavonoids (221).

\section{CONCLUSIONS AND FUTURE PROSPECTS}

Dysfunctional epigenetics have been confirmed in various tumors in numerous studies. Flavonoids are important epigenetic regulators and are commonly consumed worldwide. In vivo and in vitro studies confirm that flavonoids can inhibit cancer by restoring dysfunctional epigenetics and intervening in DNA methylation, histone modification, and expression of noncoding RNA. Whether used alone or as an adjuvant therapy, flavonoids have shown significant efficacy. Despite many challenges, the application prospects of flavonoids are promising. Future research will provide further insights into the targeted epigenetic dimensional adjustment of flavonoids. More clinical trials are required to elucidate effects on cancer and the feasibility of clinical administration of flavonoids.

\section{AUTHOR CONTRIBUTIONS}

The research project was designed by WJ, TX, CL, and CS. WJ collected the literature, drew structures. WJ and TX wrote the 
manuscript and checked the Tables and Figures as well as grammar of manuscript. CL, JL and WZ revised the manuscript. CS and WJ participated in and helped draft the manuscript. All authors contributed to the article and approved the submitted version.

\section{REFERENCES}

1. Xu Z, Zeng S, Gong Z, Yan Y. Exosome-Based Immunotherapy: A Promising Approach for Cancer Treatment. Mol Cancer (2020) 19:160. doi: 10.1186/s12943-020-01278-3

2. Rashkin SR, Graff RE, Kachuri L, Thai KK, Alexeeff SE, Blatchins MA, et al. Pan-Cancer Study Detects Genetic Risk Variants and Shared Genetic Basis in Two Large Cohorts. Nat Commun (2020) 11:4423. doi: 10.1038/s41467020-18246-6

3. Jones P, Ohtani H, Chakravarthy A, De Carvalho D. Epigenetic Therapy in Immune-Oncology. Nat Rev Cancer (2019) 19:151-61. doi: 10.1038/s41568019-0109-9

4. Wooten M, Snedeker J, Nizami Z, Yang X, Ranjan R, Urban E, et al. Asymmetric Histone Inheritance Via Strand-Specific Incorporation and Biased Replication Fork Movement. Nat Struct Mol Biol (2019) 26:732-43. doi: 10.1038/s41594-019-0269-Z

5. Abdelsamed HA, Zebley CC, Nguyen H, Rutishauser RL, Fan Y, Ghoneim HE, et al. Beta Cell-Specific CD8(+) T Cells Maintain Stem Cell MemoryAssociated Epigenetic Programs During Type 1 Diabetes. Nat Immunol (2020) 21:578-87. doi: 10.1038/s41590-020-0633-5

6. Robertson KD, Wolffe AP. DNA Methylation in Health and Disease. Nat Rev Genet (2000) 1:11-9. doi: 10.1038/35049533

7. Hinohara K, Polyak K. Intratumoral Heterogeneity: More Than Just Mutations. Trends Cell Biol (2019) 29:569-79. doi: 10.1016/j.tcb.2019.03.003

8. Tidwell TR, Soreide K, Hagland HR. Aging, Metabolism, and Cancer Development: From Peto's Paradox to the Warburg Effect. Aging Dis (2017) 8:662-76. doi: 10.14336/AD.2017.0713

9. Tiffon C. The Impact of Nutrition and Environmental Epigenetics on Human Health and Disease. Int J Mol Sci (2018) 19. doi: 10.3390/ ijms 19113425

10. Rizzo HE, Escaname EN, Alana NB, Lavender E, Gelfond J, Fernandez R, et al. Maternal Diabetes and Obesity Influence the Fetal Epigenome in a Largely Hispanic Population. Clin Epigenet (2020) 12:34. doi: 10.1186/ s13148-020-0824-9

11. Cheng Z, Zheng L, Almeida FA. Epigenetic Reprogramming in Metabolic Disorders: Nutritional Factors and Beyond. J Nutr Biochem (2018) 54:1-10. doi: 10.1016/j.jnutbio.2017.10.004

12. Bondonno NP, Dalgaard F, Kyro C, Murray K, Bondonno CP, Lewis JR, et al. Flavonoid Intake is Associated With Lower Mortality in the Danish Diet Cancer and Health Cohort. Nat Commun (2019) 10:3651. doi: 10.1038/ s41467-019-11622-x

13. Shanmugam K, Ravindran S, Kurian GA, Rajesh M. Fisetin Confers Cardioprotection Against Myocardial Ischemia Reperfusion Injury by Suppressing Mitochondrial Oxidative Stress and Mitochondrial Dysfunction and Inhibiting Glycogen Synthase Kinase 3beta Activity. Oxid Med Cell Longev (2018) 2018:9173436. doi: 10.1155/2018/9173436

14. Kim TW, Lee SY, Kim M, Cheon C, Ko SG. Kaempferol Induces Autophagic Cell Death Via IRE1-JNK-CHOP Pathway and Inhibition of G9a in Gastric Cancer Cells. Cell Death Dis (2018) 9:875. doi: 10.1038/s41419-018-0930-1

15. Sheng J, Shi W, Guo H, Long W, Wang Y, Qi J, et al. The Inhibitory Effect of (-)-Epigallocatechin-3-Gallate on Breast Cancer Progression Via Reducing SCUBE2 Methylation and DNMT Activity. Molecules (2019) 24. doi: 10.3390/molecules24162899

16. Deb G, Shankar E, Thakur VS, Ponsky LE, Bodner DR, Fu P, et al. Green Tea-Induced Epigenetic Reactivation of Tissue Inhibitor of Matrix Metalloproteinase-3 Suppresses Prostate Cancer Progression Through Histone-Modifying Enzymes. Mol Carcinog (2019) 58:1194-207. doi: $10.1002 / \mathrm{mc} .23003$

17. Zhao Y, Chen X, Jiang J, Wan X, Wang Y, Xu P. Epigallocatechin Gallate Reverses Gastric Cancer by Regulating the Long Noncoding RNA

\section{FUNDING}

This work was supported by the National Natural Science Foundation of China (grant number 81973677).

LINC00511/miR-29b/KDM2A Axis. Biochim Biophys Acta Mol Basis Dis (2020) 1866:165856. doi: 10.1016/j.bbadis.2020.165856

18. Bates SE. Epigenetic Therapies for Cancer. N Engl J Med (2020) 383:650-63. doi: 10.1056/NEJMra1805035

19. Jones PA, Issa JP, Baylin S. Targeting the Cancer Epigenome for Therapy. Nat Rev Genet (2016) 17:630-41. doi: 10.1038/nrg.2016.93

20. Feng X, Zhang Y, Zhang C, Lai X, Zhang Y, Wu J, et al. NanomaterialMediated Autophagy: Coexisting Hazard and Health Benefits in Biomedicine. Part Fibre Toxicol (2020) 17:53. doi: 10.1186/s12989-02000372-0

21. Jiang X, Liu Y, Ma L, Ji R, Qu Y, Xin Y, et al. Chemopreventive Activity of Sulforaphane. Drug Des Devel Ther (2018) 12:2905-13. doi: 10.2147/ DDDT.S100534

22. Huh I, Wu X, Park T, Yi SV. Detecting Differential DNA Methylation From Sequencing of Bisulfite Converted DNA of Diverse Species. Brief Bioinform (2019) 20:33-46. doi: 10.1093/bib/bbx077

23. Peng Y, Shui L, Xie J, Liu S. Development and Validation of a Novel 15CpG-Based Signature for Predicting Prognosis in Triple-Negative Breast Cancer. J Cell Mol Med (2020) 24:9378-87. doi: 10.1111/jcmm.15588

24. Zhang Y, Fukui N, Yahata M, Katsuragawa Y, Tashiro T, Ikegawa S, et al. Identification of DNA Methylation Changes Associated With Disease Progression in Subchondral Bone With Site-Matched Cartilage in Knee Osteoarthritis. Sci Rep (2016) 6:34460. doi: 10.1038/srep34460

25. Liu D, Meng X, Wu D, Qiu Z, Luo H. A Natural Isoquinoline Alkaloid With Antitumor Activity: Studies of the Biological Activities of Berberine. Front Pharmacol (2019) 10:9. doi: 10.3389/fphar.2019.00009

26. Sumei S, Xiangyun K, Fenrong C, Xueguang S, Sijun H, Bin B, et al. Hypermethylation of DHRS3 as a Novel Tumor Suppressor Involved in Tumor Growth and Prognosis in Gastric Cancer. Front Cell Dev Biol (2021) 9:624871. doi: 10.3389/fcell.2021.624871

27. Fu S, Wu H, Zhang H, Lian CG, Lu Q. DNA Methylation/ Hydroxymethylation in Melanoma. Oncotarget (2017) 8:78163-73. doi: 10.18632/oncotarget.18293

28. Smith J, Sen S, Weeks RJ, Eccles MR, Chatterjee A. Promoter DNA Hypermethylation and Paradoxical Gene Activation. Trends Cancer (2020) 6:392-406. doi: 10.1016/j.trecan.2020.02.007

29. Koch A, Joosten SC, Feng Z, de Ruijter TC, Draht MX, Melotte V, et al. Analysis of DNA Methylation in Cancer: Location Revisited. Nat Rev Clin Oncol (2018) 15:459-66. doi: 10.1038/s41571-018-0004-4

30. Tzelepi V, Logotheti S, Efstathiou E, Troncoso P, Aparicio A, Sakellakis M, et al. Epigenetics and Prostate Cancer: Defining the Timing of DNA Methyltransferase Deregulation During Prostate Cancer Progression. Pathology (2020) 52:218-27. doi: 10.1016/j.pathol.2019.10.006

31. Zhang H, Lang Z, Zhu JK. Dynamics and Function of DNA Methylation in Plants. Nat Rev Mol Cell Biol (2018) 19:489-506. doi: 10.1038/s41580-018-0016-Z

32. Reichard JF, Puga A. Effects of Arsenic Exposure on DNA Methylation and Epigenetic Gene Regulation. Epigenomics (2010) 2:87-104. doi: 10.2217/epi.09.45

33. Voisin S, Eynon N, Yan X, Bishop DJ. Exercise Training and DNA Methylation in Humans. Acta Physiol (Oxf) (2015) 213:39-59. doi: 10.1111/apha.12414

34. Ferreira HJ, Esteller M. CpG Islands in Cancer: Heads, Tails, and Sides. Methods Mol Biol (2018) 1766:49-80. doi: 10.1007/978-1-4939-7768-0_4

35. Esteller M. Cancer Epigenomics: DNA Methylomes and HistoneModification Maps. Nat Rev Genet (2007) 8:286-98. doi: 10.1038/nrg2005

36. Lawrence M, Daujat S, Schneider R. Lateral Thinking: How Histone Modifications Regulate Gene Expression. Trends Genet (2016) 32:42-56. doi: 10.1016/j.tig.2015.10.007

37. Aebersold R, Mann M. Mass-Spectrometric Exploration of Proteome Structure and Function. Nature (2016) 537:347-55. doi: 10.1038/ nature 19949 
38. Stoll S, Wang C, Qiu H. DNA Methylation and Histone Modification in Hypertension. Int J Mol Sci (2018) 19. doi: 10.3390/ijms19041174

39. Wysocka J, Milne TA, Allis CD. Taking LSD 1 to a New High. Cell (2005) 122:654-8. doi: 10.1016/j.cell.2005.08.022

40. Grunstein M. Histone Acetylation in Chromatin Structure and Transcription. Nature (1997) 389:349-52. doi: 10.1038/38664

41. Eckschlager T, Plch J, Stiborova M, Hrabeta J. Histone Deacetylase Inhibitors as Anticancer Drugs. Int J Mol Sci (2017) 18. doi: 10.3390/ ijms 18071414

42. Fozouni P, Ott M. How Cells Hush a Viral Invader. Nature (2018) 564:1934. doi: 10.1038/d41586-018-07493-9

43. Salek Farrokhi A, Mohammadlou M, Abdollahi M, Eslami M, Yousefi B. Histone Deacetylase Modifications by Probiotics in Colorectal Cancer. J Gastrointest Cancer (2020) 51:754-64. doi: 10.1007/s12029-019-00338-2

44. Tong Q, Weaver MR, Kosmacek EA, O'Connor BP, Harmacek L, Venkataraman S, et al. MnTE-2-Pyp Reduces Prostate Cancer Growth and Metastasis by Suppressing P300 Activity and P300/HIF-1/CREB Binding to the Promoter Region of the PAI-1 Gene. Free Radic Biol Med (2016) 94:185-94. doi: 10.1016/j.freeradbiomed.2016.02.036

45. Chen K, Zhang F, Ding J, Liang Y, Zhan Z, Zhan Y, et al. Histone Methyltransferase SETDB1 Promotes the Progression of Colorectal Cancer by Inhibiting the Expression of TP53. J Cancer (2017) 8:3318-30. doi: $10.7150 /$ jca. 20482

46. Chen R, Zhang M, Zhou Y, Guo W, Yi M, Zhang Z, et al. The Application of Histone Deacetylases Inhibitors in Glioblastoma. J Exp Clin Cancer Res (2020) 39:138. doi: 10.1186/s13046-020-01643-6

47. Thiagarajan D, Vedantham S, Ananthakrishnan R, Schmidt AM, Ramasamy R. Mechanisms of Transcription Factor Acetylation and Consequences in Hearts. Biochim Biophys Acta (2016) 1862:2221-31. doi: 10.1016/ j.bbadis.2016.08.011

48. Keppler BR, Archer TK. Chromatin-Modifying Enzymes as Therapeutic Targets-Part 1. Expert Opin Ther Targets (2008) 12:1301-12. doi: 10.1517/ 14728222.12.10.1301

49. Falkenberg KJ, Johnstone RW. Histone Deacetylases and Their Inhibitors in Cancer, Neurological Diseases and Immune Disorders. Nat Rev Drug Discov (2014) 13:673-91. doi: 10.1038/nrd4360

50. Trisciuoglio D, Di Martile M, Del Bufalo D. Emerging Role of Histone Acetyltransferase in Stem Cells and Cancer. Stem Cells Int (2018) 2018:8908751. doi: 10.1155/2018/8908751

51. Tie J, Zhang X, Fan D. Epigenetic Roles in the Malignant Transformation of Gastric Mucosal Cells. Cell Mol Life Sci (2016) 73:4599-610. doi: 10.1007/ s00018-016-2308-9

52. Fu DG. Epigenetic Alterations in Gastric Cancer (Review). Mol Med Rep (2015) 12:3223-30. doi: $10.3892 / \mathrm{mmr} .2015 .3816$

53. Satomura S, Sakata Y, Omichi K, Ikenaka T. Alpha-Amylase Assay With Use of a Benzyl Derivative of P-Nitrophenyl Alpha-Maltopentaoside, BG5P. Clin Chim Acta (1988) 174:315-23. doi: 10.1016/0009-8981(88)90058-7

54. Kim S, Kaang BK. Epigenetic Regulation and Chromatin Remodeling in Learning and Memory. Exp Mol Med (2017) 49:e281. doi: 10.1038/ emm.2016.140

55. Ono R, Taki T, Taketani T, Taniwaki M, Kobayashi H, Hayashi YLCX. Leukemia-Associated Protein With a CXXC Domain, is Fused to MLL in Acute Myeloid Leukemia With Trilineage Dysplasia Having t()(q22;q23). Cancer Res (2002) 62:4075-80. doi: 10.1016/S0165-4608(02)00534-4

56. Shi Y, Lan F, Matson C, Mulligan P, Whetstine JR, Cole PA, et al. Histone Demethylation Mediated by the Nuclear Amine Oxidase Homolog LSD1. Cell (2004) 119:941-53. doi: 10.1016/j.cell.2004.12.012

57. Chen X, Liang H, Zhang J, Zen K, Zhang CY. Secreted MicroRNAs: A New Form of Intercellular Communication. Trends Cell Biol (2012) 22:125-32. doi: 10.1016/j.tcb.2011.12.001

58. Mohr AM, Mott JL. Overview of microRNA Biology. Semin Liver Dis (2015) 35:3-11. doi: 10.1055/s-0034-1397344

59. Youn SW, Park KK. Small-Nucleic-Acid-Based Therapeutic Strategy Targeting the Transcription Factors Regulating the Vascular Inflammation, Remodeling and Fibrosis in Atherosclerosis. Int J Mol Sci (2015) 16:11804-33. doi: 10.3390/ijms160511804

60. Cantini L, Bertoli G, Cava C, Dubois T, Zinovyev A, Caselle M, et al. Identification of Microrna Clusters Cooperatively Acting on Epithelial to
Mesenchymal Transition in Triple Negative Breast Cancer. Nucleic Acids Res (2019) 47:2205-15. doi: 10.1093/nar/gkz016

61. Elhamamsy AR, El Sharkawy MS, Zanaty AF, Mahrous MA, Mohamed AE, Abushaaban EA. Circulating miR-92a, miR-143 and miR-342 in Plasma are Novel Potential Biomarkers for Acute Myeloid Leukemia. Int J Mol Cell Med (2017) 6:77-86. doi: 10.22088/acadpub.BUMS.6.2.2

62. Toyota M, Suzuki H, Sasaki Y, Maruyama R, Imai K, Shinomura Y, et al. Epigenetic Silencing of microRNA-34b/c and B-cell Translocation Gene 4 is Associated With CpG Island Methylation in Colorectal Cancer. Cancer Res (2008) 68:4123-32. doi: 10.1158/0008-5472.CAN-08-0325

63. Yang H, Lan P, Hou Z, Guan Y, Zhang J, Xu W, et al. Histone Deacetylase Inhibitor SAHA Epigenetically Regulates miR-17-92 Cluster and MCM7 to Upregulate Mica Expression in Hepatoma. Br J Cancer (2015) 112:112-21. doi: 10.1038/bjc.2014.547

64. Xuan P, Jia L, Zhang T, Sheng N, Li X, Li J. LDAPred: A Method Based on Information Flow Propagation and a Convolutional Neural Network for the Prediction of Disease-Associated Lncrnas. Int J Mol Sci (2019) 20. doi: $10.3390 / \mathrm{ijms} 20184458$

65. Li Z, Lu M, Zhou Y, Xu L, Jiang Y, Liu Y, et al. Role of Long Non-Coding RNAs in the Chemoresistance of Gastric Cancer: A Systematic Review. Onco Targets Ther (2021) 14:503-18. doi: 10.2147/OTT.S294378

66. Chen Z, Zhang K, Qiu W, Luo Y, Pan Y, Li J, et al. Genome-Wide Identification of Long Noncoding RNAs and Their Competing Endogenous RNA Networks Involved in the Odontogenic Differentiation of Human Dental Pulp Stem Cells. Stem Cell Res Ther (2020) 11:114. doi: 10.1186/s13287-020-01622-w

67. Yoshioka H, Yoshiko Y. The Roles of Long Non-Protein-Coding RNAs in Osteo-Adipogenic Lineage Commitment. Int J Mol Sci (2017) 18. doi: $10.3390 /$ ijms 18061236

68. Xu X, Zhao Z, Li G. The Therapeutic Potential of MicroRNAs in Atrial Fibrillation. Mediators Inflamm (2020) 2020:3053520. doi: 10.1155/2020/ 3053520

69. Liao T, Qu N, Shi RL, Guo K, Ma B, Cao YM, et al. BRAF-Activated LncRNA Functions as a Tumor Suppressor in Papillary Thyroid Cancer. Oncotarget (2017) 8:238-47. doi: 10.18632/oncotarget.10825

70. Kussmann M, Morine MJ, Hager J, Sonderegger B, Kaput J. Perspective: A Systems Approach to Diabetes Research. Front Genet (2013) 4:205. doi: 10.3389/fgene.2013.00205

71. Link A, Balaguer F, Goel A. Cancer Chemoprevention by Dietary Polyphenols: Promising Role for Epigenetics. Biochem Pharmacol (2010) 80:1771-92. doi: 10.1016/j.bcp.2010.06.036

72. Vue B, Zhang S, Chen QH. Flavonoids With Therapeutic Potential in Prostate Cancer. Anticancer Agents Med Chem (2016) 16:1205-29. doi: $10.2174 / 1871520615666151008122622$

73. Kopustinskiene DM, Jakstas V, Savickas A, Bernatoniene J. Flavonoids as Anticancer Agents. Nutrients (2020) 12. doi: 10.3390/nu12020457

74. Wen L, Jiang Y, Yang J, Zhao Y, Tian M, Yang B. Structure, Bioactivity, and Synthesis of Methylated Flavonoids. Ann N Y Acad Sci (2017) 1398:120-9. doi: $10.1111 /$ nyas. 13350

75. Liskova A, Samec M, Koklesova L, Samuel SM, Zhai K, Al-Ishaq RK, et al. Flavonoids Against the SARS-CoV-2 Induced Inflammatory Storm. BioMed Pharmacother (2021) 138:111430. doi: 10.1016/j.biopha.2021.111430

76. Gibellini L, Pinti M, Nasi M, Montagna JP, De Biasi S, Roat E, et al. Quercetin and Cancer Chemoprevention. Evid Based Complement Alternat Med (2011) 2011:591356. doi: 10.1093/ecam/neq053

77. Ayoobi F, Shamsizadeh A, Fatemi I, Vakilian A, Allahtavakoli M, Hassanshahi $\mathrm{G}$, et al. Bio-Effectiveness of the Main Flavonoids of Achillea Millefolium in the Pathophysiology of Neurodegenerative Disorders- A Review. Iran J Basic Med Sci (2017) 20:604-12. doi: 10.22038/IJBMS.2017.8827

78. Fan LL, Zhang SS, Yao MX, Jiang Y, Su M, Wang XL, et al. [Changes in Chemical Compositions of Chrysanthemi Flos After Frying and Protective Effects on CCl_4-induced Acute Liver Injury in Mice]. Zhongguo Zhong Yao Za Zhi (2020) 45:3144-54. doi: 10.19540/j.cnki.cjcmm.20200424.303

79. Zheng G, Yang X, Chen B, Chao Y, Hu P, Cai Y, et al. Identification and Determination of Chemical Constituents of Citrus Reticulata Semen Through Ultra High Performance Liquid Chromatography Combined With Q Exactive Orbitrap Tandem Mass Spectrometry. J Sep Sci (2020) 43:438-51. doi: 10.1002/jssc.201900641 
80. Feng Y, Dunshea FR, Suleria HAR. LC-ESI-QTOF/MS Characterization of Bioactive Compounds From Black Spices and Their Potential Antioxidant Activities. J Food Sci Technol (2020) 57:4671-87. doi: 10.1007/s13197-020-04504-4

81. Kurek-Gorecka A, Gorecki M, Rzepecka-Stojko A, Balwierz R, Stojko J. Bee Products in Dermatology and Skin Care. Molecules (2020) 25:556. doi: 10.3390/molecules25030556

82. Chan KKL, Siu MKY, Jiang YX, Wang JJ, Leung THY, Ngan HYS. Estrogen Receptor Modulators Genistein, Daidzein and ERB-041 Inhibit Cell Migration, Invasion, Proliferation and Sphere Formation Via Modulation of FAK and PI3K/AKT Signaling in Ovarian Cancer. Cancer Cell Int (2018) 18:65. doi: 10.1186/s12935-018-0559-2

83. Ru J, Li P, Wang J, Zhou W, Li B, Huang C, et al. TCMSP: A Database of Systems Pharmacology for Drug Discovery From Herbal Medicines. J Cheminform (2014) 6:13. doi: 10.1186/1758-2946-6-13

84. Dong JY, Kimura T, Ikehara S, Cui M, Kawanishi Y, Kimura T, et al. Soy Consumption and Incidence of Gestational Diabetes Mellitus: The Japan Environment and Children's Study. Eur J Nutr (2021) 60:897-904. doi: 10.1007/s00394-020-02294-1

85. Nugroho A, Kim EJ, Choi JS, Park HJ. Simultaneous Quantification and Peroxynitrite-Scavenging Activities of Flavonoids in Polygonum Aviculare L. Herb. J Pharm BioMed Anal (2014) 89:93-8. doi: 10.1016/j.jpba. 2013.10.037

86. Wang $\mathrm{W}$, Lin $\mathrm{P}, \mathrm{Ma} \mathrm{L}, \mathrm{Xu} \mathrm{K}$, Lin X. Separation and Determination of Flavonoids in Three Traditional Chinese Medicines by Capillary Electrophoresis With Amperometric Detection. J Sep Sci (2016) 39:135762. doi: $10.1002 /$ jssc.201501287

87. Huang G, Zeng Y, Wei L, Yao Y, Dai J, Liu G, et al. Comparative Transcriptome Analysis of Mulberry Reveals Anthocyanin Biosynthesis Mechanisms in Black (Morus Atropurpurea Roxb.) and White (Morus Alba L.) Fruit Genotypes. BMC Plant Biol (2020) 20:279. doi: 10.1186/ s12870-020-02486-1

88. Jia Q, Zhang S, Zhang H, Yang X, Cui X, Su Z, et al. A Comparative Study on Polyphenolic Composition of Berries From the Tibetan Plateau by UPLC-QOrbitrap Ms System. Chem Biodivers (2020) 17:e2000033. doi: 10.1002/ cbdv.202000033

89. Beck S, Stengel J. Mass Spectrometric Imaging of Flavonoid Glycosides and Biflavonoids in Ginkgo Biloba L. Phytochemistry (2016) 130:201-6. doi: 10.1016/j.phytochem.2016.05.005

90. Ditano-Vazquez P, Torres-Pena JD, Galeano-Valle F, Perez-Caballero AI, Demelo-Rodriguez P, Lopez-Miranda J, et al. The Fluid Aspect of the Mediterranean Diet in the Prevention and Management of Cardiovascular Disease and Diabetes: The Role of Polyphenol Content in Moderate Consumption of Wine and Olive Oil. Nutrients (2019) 11:2833. doi: 10.3390/nu11112833

91. Yang X, Ma Y, Li L. Beta-Glucosidase From Tartary Buckwheat Immobilization on Bifunctionalized Nano-Magnetic Iron Oxide and its Application in Tea Soup for Aroma and Flavonoid Aglycone Enhancement. Food Funct (2019) 10:5461-72. doi: 10.1039/c9fo00283a

92. Rassi CM, Lieberherr M, Chaumaz G, Pointillart A, Cournot G. Modulation of Osteoclastogenesis in Porcine Bone Marrow Cultures by Quercetin and Rutin. Cell Tissue Res (2005) 319:383-93. doi: 10.1007/s00441-004-1053-9

93. Duan Y, Eduardo Melo Santiago F, Rodrigues Dos Reis A, de Figueiredo MA, Zhou S, Thannhauser TW, et al. Genotypic Variation of Flavonols and Antioxidant Capacity in Broccoli. Food Chem (2021) 338:127997. doi: 10.1016/j.foodchem.2020.127997

94. Shin KC, Nam HK, Oh DK. Hydrolysis of Flavanone Glycosides by BetaGlucosidase From Pyrococcus Furiosus and its Application to the Production of Flavanone Aglycones From Citrus Extracts. J Agric Food Chem (2013) 61:11532-40. doi: 10.1021/jf403332e

95. Justesen U, Knuthsen P, Leth T. Quantitative Analysis of Flavonols, Flavones, and Flavanones in Fruits, Vegetables and Beverages by HighPerformance Liquid Chromatography With Photo-Diode Array and Mass Spectrometric Detection. J Chromatogr A (1998) 799:101-10. doi: 10.1016/ s0021-9673(97)01061-3

96. Mouly PP, Arzouyan CR, Gaydou EM, Estienne JM. Differentiation of Citrus Juices by Factorial Discriminant Analysis Using Liquid Chromatography of Flavones Glycosides. J Agric Food Chem (1994) 42:70-9. doi: 10.1021/ jf00037a011
97. Hollman PC, Arts IC. Flavonols, Flavones and Flavanols - Nature, Occurrence and Dietary Burden. J Sci Food Agric (2000) 80:1081-93. doi: 10.1002/(SICI) 1097-0010(20000515)80:7<1081::AID-JSFA566>3.0.CO;2-G

98. Lee YM, Yoon Y, Yoon H, Park HM, Song S, Yeum KJ. Dietary Anthocyanins Against Obesity and Inflammation. Nutrients (2017) 9:1089. doi: 10.3390/nu9101089

99. Kozlowska A, Szostak-Wegierek D. Flavonoids-Food Sources and Health Benefits. Rocz Panstw Zakl Hig (2014) 65:79-85.

100. Kumar S, Pandey AK. Chemistry and Biological Activities of Flavonoids: An Overview. ScientificWorldJournal (2013) 2013:162750. doi: 10.1155/2013/162750

101. Santini A, Novellino E. Nutraceuticals in Hypercholesterolaemia: An Overview. Br J Pharmacol (2017) 174:1450-63. doi: 10.1111/bph.13636

102. Georgiev V, Ananga A, Tsolova V. Recent Advances and Uses of Grape Flavonoids as Nutraceuticals. Nutrients (2014) 6:391-415. doi: 10.3390/nu6010391

103. Jager AK, Saaby L. Flavonoids and the CNS. Molecules (2011) 16:1471-85. doi: 10.3390/molecules 16021471

104. Imran M, Salehi B, Sharifi-Rad J, Aslam Gondal T, Saeed F, Imran A, et al. Kaempferol: A Key Emphasis to Its Anticancer Potential. Molecules (2019) 24. doi: $10.3390 /$ molecules 24122277

105. Devi KP, Malar DS, Nabavi SF, Sureda A, Xiao J, Nabavi SM, et al. Kaempferol and Inflammation: From Chemistry to Medicine. Pharmacol Res (2015) 99:1-10. doi: 10.1016/j.phrs.2015.05.002

106. Calderon-Montano JM, Burgos-Moron E, Perez-Guerrero C, Lopez-Lazaro M. A Review on the Dietary Flavonoid Kaempferol. Mini Rev Med Chem (2011) 11:298-344. doi: 10.2174/138955711795305335

107. Gates MA, Tworoger SS, Hecht JL, De Vivo I, Rosner B, Hankinson SE. A Prospective Study of Dietary Flavonoid Intake and Incidence of Epithelial Ovarian Cancer. Int J Cancer (2007) 121:2225-32. doi: 10.1002/ijc.22790

108. Nothlings U, Murphy SP, Wilkens LR, Henderson BE, Kolonel LN. Flavonols and Pancreatic Cancer Risk: The Multiethnic Cohort Study. Am J Epidemiol (2007) 166:924-31. doi: 10.1093/aje/kwm172

109. Berger A, Venturelli S, Kallnischkies M, Bocker A, Busch C, Weiland T, et al. Kaempferol, a New Nutrition-Derived Pan-Inhibitor of Human Histone Deacetylases. J Nutr Biochem (2013) 24:977-85. doi: 10.1016/j.jnutbio. 2012.07.001

110. Lu L, Wang Y, Ou R, Feng Q, Ji L, Zheng H, et al. DACT2 Epigenetic Stimulator Exerts Dual Efficacy for Colorectal Cancer Prevention and Treatment. Pharmacol Res (2018) 129:318-28. doi: 10.1016/j.phrs.2017.11.032

111. Wang L, Wu H, Yang F, Dong W. The Protective Effects of Myricetin Against Cardiovascular Disease. J Nutr Sci Vitaminol (Tokyo) (2019) 65:470-6. doi: $10.3177 /$ jnsv. 65.470

112. Xie Y, Wang Y, Xiang W, Wang Q, Cao Y. Molecular Mechanisms of the Action of Myricetin in Cancer. Mini Rev Med Chem (2020) 20:123-33. doi: 10.2174/1389557519666191018112756

113. Jiang $M$, Zhu M, Wang L, Yu S. Anti-Tumor Effects and Associated Molecular Mechanisms of Myricetin. BioMed Pharmacother (2019) 120:109506. doi: 10.1016/j.biopha.2019.109506

114. Semwal DK, Semwal RB, Combrinck S, Viljoen A. Myricetin: A Dietary Molecule With Diverse Biological Activities. Nutrients (2016) 8:90. doi: $10.3390 /$ nu 8020090

115. Lee WJ, Shim JY, Zhu BT. Mechanisms for the Inhibition of DNA Methyltransferases by Tea Catechins and Bioflavonoids. Mol Pharmacol (2005) 68:1018-30. doi: 10.1124/mol.104.008367

116. Gurunathan S, Qasim M, Park C, Yoo H, Choi DY, Song H, et al. Cytotoxicity and Transcriptomic Analysis of Silver Nanoparticles in Mouse Embryonic Fibroblast Cells. Int J Mol Sci (2018) 19. doi: 10.3390/ ijms 19113618

117. Basu Mallik S, Pai A, Shenoy RR, Jayashree BS. Novel Flavonol Analogues as Potential Inhibitors of JMJD3 Histone Demethylase-a Study Based on Molecular Modelling. J Mol Graph Model (2017) 72:81-7. doi: 10.1016/ j.jmgm.2016.12.002

118. Hong KS, Park JI, Kim MJ, Kim HB, Lee JW, Dao TT, et al. Involvement of SIRT1 in Hypoxic Down-Regulation of c-Myc and Beta-Catenin and Hypoxic Preconditioning Effect of Polyphenols. Toxicol Appl Pharmacol (2012) 259:210-8. doi: 10.1016/j.taap.2011.12.025

119. Andres S, Pevny S, Ziegenhagen R, Bakhiya N, Schafer B, Hirsch-Ernst KI, et al. Safety Aspects of the Use of Quercetin as a Dietary Supplement. Mol Nutr Food Res (2018) 62. doi: 10.1002/mnfr.201700447 
120. Marunaka Y, Marunaka R, Sun H, Yamamoto T, Kanamura N, Inui T, et al. Actions of Quercetin, a Polyphenol, on Blood Pressure. Molecules (2017) 22. doi: 10.3390/molecules22020209

121. Patel RV, Mistry BM, Shinde SK, Syed R, Singh V, Shin HS. Therapeutic Potential of Quercetin as a Cardiovascular Agent. Eur J Med Chem (2018) 155:889-904. doi: 10.1016/j.ejmech.2018.06.053

122. Sharma V, Kumar L, Mohanty SK, Maikhuri JP, Rajender S, Gupta G. Sensitization of Androgen Refractory Prostate Cancer Cells to AntiAndrogens Through Re-Expression of Epigenetically Repressed Androgen Receptor - Synergistic Action of Quercetin and Curcumin. Mol Cell Endocrinol (2016) 431:12-23. doi: 10.1016/j.mce.2016.04.024

123. Zheng NG, Wang JL, Yang SL, Wu JL. Aberrant Epigenetic Alteration in Eca9706 Cells Modulated by Nanoliposomal Quercetin Combined With Butyrate Mediated Via epigenetic-NF-kappaB Signaling. Asian Pac J Cancer Prev (2014) 15:4539-43. doi: 10.7314/apjcp.2014.15.11.4539

124. Wang P, Phan T, Gordon D, Chung S, Henning SM, Vadgama JV. Arctigenin in Combination With Quercetin Synergistically Enhances the Antiproliferative Effect in Prostate Cancer Cells. Mol Nutr Food Res (2015) 59:250-61. doi: 10.1002/mnfr.201400558

125. Pham TND, Stempel S, Shields MA, Spaulding C, Kumar K, Bentrem DJ, et al. Quercetin Enhances the Anti-Tumor Effects of BET Inhibitors by Suppressing hnRNPA1. Int J Mol Sci (2019) 20. doi: 10.3390/ijms20174293

126. Pratheeshkumar P, Son YO, Divya SP, Wang L, Turcios L, Roy RV, et al. Quercetin Inhibits Cr(VI)-Induced Malignant Cell Transformation by Targeting miR-21-PDCD4 Signaling Pathway. Oncotarget (2017) 8:5211831. doi: $10.18632 /$ oncotarget. 10130

127. Nwaeburu CC, Abukiwan A, Zhao Z, Herr I. Quercetin-Induced miR-200b$3 p$ Regulates the Mode of Self-Renewing Divisions in Pancreatic Cancer. Mol Cancer (2017) 16:23. doi: 10.1186/s12943-017-0589-8

128. Lou G, Liu Y, Wu S, Xue J, Yang F, Fu H, et al. The p53/miR-34a/SIRT1 Positive Feedback Loop in Quercetin-Induced Apoptosis. Cell Physiol Biochem (2015) 35:2192-202. doi: 10.1159/000374024

129. Tao SF, He HF, Chen Q. Quercetin Inhibits Proliferation and Invasion Acts by Up-Regulating miR-146a in Human Breast Cancer Cells. Mol Cell Biochem (2015) 402:93-100. doi: 10.1007/s11010-014-2317-7

130. Zhang X, Guo Q, Chen J, Chen Z. Quercetin Enhances Cisplatin Sensitivity of Human Osteosarcoma Cells by Modulating microRNA-217-KRAS Axis. Mol Cells (2015) 38:638-42. doi: 10.14348/molcells.2015.0037

131. Guo J, Feng Z, Huang Z, Wang H, Lu W. MicroRNA-217 Functions as a Tumour Suppressor Gene and Correlates With Cell Resistance to Cisplatin in Lung Cancer. Mol Cells (2014) 37:664-71. doi: 10.14348/molcells.2014.0121

132. Zheng Y, Zhang R, Shi W, Li L, Liu H, Chen Z, et al. Metabolism and Pharmacological Activities of the Natural Health-Benefiting Compound Diosmin. Food Funct (2020) 11:8472-92. doi: 10.1039/d0fo01598a

133. Klimek-Szczykutowicz M, Szopa A, Ekiert H. Citrus Limon (Lemon) Phenomenon-A Review of the Chemistry, Pharmacological Properties, Applications in the Modern Pharmaceutical, Food, and Cosmetics Industries, and Biotechnological Studies. Plants (Basel) (2020) 9. doi: 10.3390/plants9010119

134. Lewinska A, Siwak J, Rzeszutek I, Wnuk M. Diosmin Induces Genotoxicity and Apoptosis in DU145 Prostate Cancer Cell Line. Toxicol In Vitro (2015) 29:417-25. doi: 10.1016/j.tiv.2014.12.005

135. Kasiri N, Rahmati M, Ahmadi L, Eskandari N. The Significant Impact of Apigenin on Different Aspects of Autoimmune Disease. Inflammopharmacology (2018) 26:1359-73. doi: 10.1007/s10787-018-0531-8

136. Salehi B, Venditti A, Sharifi-Rad M, Kregiel D, Sharifi-Rad J, Durazzo A, et al. The Therapeutic Potential of Apigenin. Int J Mol Sci (2019) 20. doi: 10.3390/ijms20061305

137. Wang M, Firrman J, Liu L, Yam K. A Review on Flavonoid Apigenin: Dietary Intake, ADME, Antimicrobial Effects, and Interactions With Human Gut Microbiota. BioMed Res Int (2019) 2019:7010467. doi: 10.1155/2019/ 7010467

138. Kowalczyk A, Bodalska A, Miranowicz M, Karlowicz-Bodalska K. Insights Into Novel Anticancer Applications for Apigenin. Adv Clin Exp Med (2017) 26:1143-6. doi: 10.17219/acem/41978

139. Tang D, Chen K, Huang L, Li J. Pharmacokinetic Properties and Drug Interactions of Apigenin, a Natural Flavone. Expert Opin Drug Metab Toxicol (2017) 13:323-30. doi: 10.1080/17425255.2017.1251903
140. Nabavi SM, Habtemariam S, Daglia M, Nabavi SF. Apigenin and Breast Cancers: From Chemistry to Medicine. Anticancer Agents Med Chem (2015) 15:728-35. doi: 10.2174/1871520615666150304120643

141. Tseng TH, Chien MH, Lin WL, Wen YC, Chow JM, Chen CK, et al. Inhibition of MDA-MB-231 Breast Cancer Cell Proliferation and Tumor Growth by Apigenin Through Induction of G2/M Arrest and Histone H3 Acetylation-Mediated p21(WAF1/CIP1) Expression. Environ Toxicol (2017) 32:434-44. doi: 10.1002/tox.22247

142. Paredes-Gonzalez X, Fuentes F, Su ZY, Kong AN. Apigenin Reactivates Nrf2 Anti-Oxidative Stress Signaling in Mouse Skin Epidermal JB6 P + Cells Through Epigenetics Modifications. AAPS J (2014) 16:727-35. doi: 10.1208/ s12248-014-9613-8

143. Shukla S, Fu P, Gupta S. Apigenin Induces Apoptosis by Targeting Inhibitor of Apoptosis Proteins and Ku70-Bax Interaction in Prostate Cancer. Apoptosis (2014) 19:883-94. doi: 10.1007/s10495-014-0971-6

144. Pandey M, Kaur P, Shukla S, Abbas A, Fu P, Gupta S. Plant Flavone Apigenin Inhibits HDAC and Remodels Chromatin to Induce Growth Arrest and Apoptosis in Human Prostate Cancer Cells: In Vitro and In Vivo Study. Mol Carcinog (2012) 51:952-62. doi: 10.1002/mc.20866

145. Manzoor MF, Ahmad N, Ahmed Z, Siddique R, Zeng XA, Rahaman A, et al. Novel Extraction Techniques and Pharmaceutical Activities of Luteolin and its Derivatives. J Food Biochem (2019) 43:e12974. doi: 10.1111/jfbc.12974

146. Ali F, Siddique YH. Bioavailability and Pharmaco-therapeutic Potential of Luteolin in Overcoming Alzheimer's Disease. CNS Neurol Disord Drug Targets (2019) 18:352-65. doi: 10.2174/1871527318666190319141835

147. Pandurangan AK, Esa NM. Luteolin, a Bioflavonoid Inhibits Colorectal Cancer Through Modulation of Multiple Signaling Pathways: A Review. Asian Pac J Cancer Prev (2014) 15:5501-8. doi: 10.7314/apjcp.2014.15.14.5501

148. Selvi RB, Swaminathan A, Chatterjee S, Shanmugam MK, Li F, Ramakrishnan GB, et al. Inhibition of P300 Lysine Acetyltransferase Activity by Luteolin Reduces Tumor Growth in Head and Neck Squamous Cell Carcinoma (HNSCC) Xenograft Mouse Model. Oncotarget (2015) 6:43806-18. doi: 10.18632/oncotarget.6245

149. Kanwal R, Datt M, Liu X, Gupta S. Dietary Flavones as Dual Inhibitors of DNA Methyltransferases and Histone Methyltransferases. PloS One (2016) 11:e0162956. doi: 10.1371/journal.pone.0162956

150. Ganai SA, Farooq Z, Banday S, Altaf M. In Silico Approaches for Investigating the Binding Propensity of Apigenin and Luteolin Against Class I HDAC Isoforms. Future Med Chem (2018) 10:1925-45. doi: 10.4155/fmc-2018-0020

151. Zuo Q, Wu R, Xiao X, Yang C, Yang Y, Wang C, et al. The Dietary Flavone Luteolin Epigenetically Activates the Nrf2 Pathway and Blocks Cell Transformation in Human Colorectal Cancer HCT116 Cells. J Cell Biochem (2018) 119:9573-82. doi: 10.1002/jcb.27275

152. Shoulars K, Rodriguez MA, Thompson T, Markaverich BM. Regulation of Cell Cycle and RNA Transcription Genes Identified by Microarray Analysis of PC-3 Human Prostate Cancer Cells Treated With Luteolin. J Steroid Biochem Mol Biol (2010) 118:41-50. doi: 10.1016/j.jsbmb.2009.09.016

153. Markaverich BM, Shoulars K, Rodriguez MA. Luteolin Regulation of Estrogen Signaling and Cell Cycle Pathway Genes in MCF-7 Human Breast Cancer Cells. Int J BioMed Sci (2011) 7:101-11.

154. Markaverich BM, Vijjeswarapu M, Shoulars K, Rodriguez M. Luteolin and Gefitinib Regulation of EGF Signaling Pathway and Cell Cycle Pathway Genes in PC-3 Human Prostate Cancer Cells. J Steroid Biochem Mol Biol (2010) 122:219-31. doi: 10.1016/j.jsbmb.2010.06.006

155. Raza W, Luqman S, Meena A. Prospects of Tangeretin as a Modulator of Cancer Targets/Pathways. Pharmacol Res (2020) 161:105202. doi: 10.1016/ j.phrs.2020.105202

156. Ashrafizadeh M, Ahmadi Z, Mohammadinejad R, Ghasemipour Afshar E. Tangeretin: A Mechanistic Review of its Pharmacological and Therapeutic Effects. J Basic Clin Physiol Pharmacol (2020) 31. doi: 10.1515/jbcpp-2019-0191

157. Braidy N, Behzad S, Habtemariam S, Ahmed T, Daglia M, Nabavi SM, et al. Neuroprotective Effects of Citrus Fruit-Derived Flavonoids, Nobiletin and Tangeretin in Alzheimer's and Parkinson's Disease. CNS Neurol Disord Drug Targets (2017) 16:387-97. doi: 10.2174/1871527316666170328113309

158. Wei GJ, Chao YH, Tung YC, Wu TY, Su ZY. A Tangeretin Derivative Inhibits the Growth of Human Prostate Cancer LNCap Cells by Epigenetically Restoring P21 Gene Expression and Inhibiting Cancer 
Stem-like Cell Proliferation. AAPS J (2019) 21:86. doi: 10.1208/s12248-0190345-7

159. Naz S, Imran M, Rauf A, Orhan IE, Shariati MA, Iahtisham Ul H, et al. Chrysin: Pharmacological and Therapeutic Properties. Life Sci (2019) 235:116797. doi: 10.1016/j.lff.2019.116797

160. Sun LP, Chen AL, Hung HC, Chien YH, Huang JS, Huang CY, et al. Chrysin: A Histone Deacetylase 8 Inhibitor With Anticancer Activity and a Suitable Candidate for the Standardization of Chinese Propolis. J Agric Food Chem (2012) 60:11748-58. doi: 10.1021/jf303261r

161. Pal-Bhadra M, Ramaiah MJ, Reddy TL, Krishnan A, Pushpavalli SN, Babu KS, et al. Plant HDAC Inhibitor Chrysin Arrest Cell Growth and Induce p21WAF1 by Altering Chromatin of STAT Response Element in A375 Cells. BMC Cancer (2012) 12:180. doi: 10.1186/1471-2407-12-180

162. Zhong X, Liu D, Jiang Z, Li C, Chen L, Xia Y, et al. Chrysin Induced Cell Apoptosis and Inhibited Invasion Through Regulation of TET1 Expression in Gastric Cancer Cells. Onco Targets Ther (2020) 13:3277-87. doi: 10.2147/ OTT.S246031

163. Krizova L, Dadakova K, Kasparovska J, Kasparovsky T. Isoflavones. Molecules (2019) 24. doi: 10.3390/molecules 24061076

164. Zhang Q, Xie H, Chen D, Yu B, Huang Z, Zheng P, et al. Dietary Daidzein Supplementation During Pregnancy Facilitates Fetal Growth in Rats. Mol Nutr Food Res (2018) 62:e1800921. doi: 10.1002/mnfr.201800921

165. Das D, Sarkar S, Bordoloi J, Wann SB, Kalita J, Manna P. Daidzein, its Effects on Impaired Glucose and Lipid Metabolism and Vascular Inflammation Associated With Type 2 Diabetes. Biofactors (2018) 44:407-17. doi: 10.1002/biof.1439

166. Vitale DC, Piazza C, Melilli B, Drago F, Salomone S. Isoflavones: Estrogenic Activity, Biological Effect and Bioavailability. Eur J Drug Metab Pharmacokinet (2013) 38:15-25. doi: 10.1007/s13318-012-0112-y

167. Zhang Y, Li Q, Chen H. DNA Methylation and Histone Modifications of Wnt Genes by Genistein During Colon Cancer Development. Carcinogenesis (2013) 34:1756-63. doi: 10.1093/carcin/bgt129

168. Zhang Y, Chen H. Genistein Attenuates WNT Signaling by Up-Regulating sFRP2 in a Human Colon Cancer Cell Line. Exp Biol Med (Maywood) (2011) 236:714-22. doi: 10.1258/ebm.2011.010347

169. Wang Z, Chen H. Genistein Increases Gene Expression by Demethylation of WNT5a Promoter in Colon Cancer Cell Line SW1116. Anticancer Res (2010) 30:4537-45. doi: 10.1097/CAD.0b013e328340dc97

170. Vardi A, Bosviel R, Rabiau N, Adjakly M, Satih S, Dechelotte P, et al. Soy Phytoestrogens Modify DNA Methylation of GSTP1, RASSF1A, EPH2 and BRCA1 Promoter in Prostate Cancer Cells. In Vivo (2010) 24:393-400. doi: 10.1089/hum.2009.157

171. Karsli-Ceppioglu S, Ngollo M, Adjakly M, Dagdemir A, Judes G, Lebert A, et al. Genome-Wide DNA Methylation Modified by Soy Phytoestrogens: Role for Epigenetic Therapeutics in Prostate Cancer? OMICS (2015) 19:20919. doi: $10.1089 / 0 m i .2014 .0142$

172. Fang MZ, Chen D, Sun Y, Jin Z, Christman JK, Yang CS. Reversal of Hypermethylation and Reactivation of P16INK4a, RARbeta, and MGMT Genes by Genistein and Other Isoflavones From Soy. Clin Cancer Res (2005) 11:7033-41. doi: 10.1158/1078-0432.CCR-05-0406

173. Zeng W, Jin L, Zhang F, Zhang C, Liang W. Naringenin as a Potential Immunomodulator in Therapeutics. Pharmacol Res (2018) 135:122-6. doi: 10.1016/j.phrs.2018.08.002

174. Hernandez-Aquino E, Muriel P. Beneficial Effects of Naringenin in Liver Diseases: Molecular Mechanisms. World J Gastroenterol (2018) 24:1679-707. doi: $10.3748 /$ wjg.v24.i16.1679

175. Den Hartogh DJ, Tsiani E. Antidiabetic Properties of Naringenin: A Citrus Fruit Polyphenol. Biomolecules (2019) 9. doi: 10.3390/biom9030099

176. Curti V, Di Lorenzo A, Rossi D, Martino E, Capelli E, Collina S, et al. Enantioselective Modulatory Effects of Naringenin Enantiomers on the Expression Levels of miR-17-3p Involved in Endogenous Antioxidant Defenses. Nutrients (2017) 9. doi: 10.3390/nu9030215

177. Fernandez-Bedmar Z, Anter J, Alonso-Moraga A, Martin de Las Mulas J, Millan-Ruiz Y, Guil-Luna S. Demethylating and Anti-Hepatocarcinogenic Potential of Hesperidin, a Natural Polyphenol of Citrus Juices. Mol Carcinog (2017) 56:1653-62. doi: 10.1002/mc.22621

178. de Oliveira MR. Phloretin-Induced Cytoprotective Effects on Mammalian Cells: A Mechanistic View and Future Directions. Biofactors (2016) 42:1340. doi: 10.1002/biof.1256
179. Nair SV, Ziaullah, Rupasinghe HP. Fatty Acid Esters of Phloridzin Induce Apoptosis of Human Liver Cancer Cells Through Altered Gene Expression. PloS One (2014) 9:e107149. doi: 10.1371/journal.pone.0107149

180. Sunil C, Xu B. An Insight Into the Health-Promoting Effects of Taxifolin (Dihydroquercetin). Phytochemistry (2019) 166:112066. doi: 10.1016/ j.phytochem.2019.112066

181. Tanaka M, Saito S, Inoue T, Satoh-Asahara N, Ihara M. Novel Therapeutic Potentials of Taxifolin for Amyloid-beta-associated Neurodegenerative Diseases and Other Diseases: Recent Advances and Future Perspectives. Int J Mol Sci (2019) 20. doi: 10.3390/ijms20092139

182. Li J, Hu L, Zhou T, Gong X, Jiang R, Li H, et al. Taxifolin Inhibits Breast Cancer Cells Proliferation, Migration and Invasion by Promoting Mesenchymal to Epithelial Transition Via Beta-Catenin Signaling. Life Sci (2019) 232:116617. doi: 10.1016/j.lfs.2019.116617

183. Zhou W, Guo Z. Taxifolin Inhibits the Scar Cell Carcinoma Growth by Inducing Apoptosis, Cell Cycle Arrest and Suppression of PI3K/AKT/mTOR Pathway. J BUON (2019) 24:853-8.

184. Kuang H, Tang Z, Zhang C, Wang Z, Li W, Yang C, et al. Taxifolin Activates the Nrf2 Anti-Oxidative Stress Pathway in Mouse Skin Epidermal JB6 P+ Cells Through Epigenetic Modifications. Int J Mol Sci (2017) 18. doi: 10.3390/ijms18071546

185. Mateen S, Raina K, Jain AK, Agarwal C, Chan D, Agarwal R. Epigenetic Modifications and p21-Cyclin B1 Nexus in Anticancer Effect of Histone Deacetylase Inhibitors in Combination With Silibinin on Non-Small Cell Lung Cancer Cells. Epigenetics (2012) 7:1161-72. doi: 10.4161/epi.22070

186. Mateen S, Raina K, Agarwal C, Chan D, Agarwal R. Silibinin Synergizes With Histone Deacetylase and DNA Methyltransferase Inhibitors in Upregulating E-Cadherin Expression Together With Inhibition of Migration and Invasion of Human Non-Small Cell Lung Cancer Cells. J Pharmacol Exp Ther (2013) 345:206-14. doi: 10.1124/jpet.113.203471

187. Anestopoulos I, Sfakianos AP, Franco R, Chlichlia K, Panayiotidis MI, Kroll DJ, et al. A Novel Role of Silibinin as a Putative Epigenetic Modulator in Human Prostate Carcinoma. Molecules (2016) 22. doi: 10.3390/ molecules22010062

188. Barros TMB, Lima APB, Almeida TC, da Silva GN. Inhibition of Urinary Bladder Cancer Cell Proliferation by Silibinin. Environ Mol Mutagen (2020) 61:445-55. doi: $10.1002 / \mathrm{em} .22363$

189. Zadeh MM, Motamed N, Ranji N, Majidi M, Falahi F. Silibinin-Induced Apoptosis and Downregulation of MicroRNA-21 and MicroRNA-155 in MCF-7 Human Breast Cancer Cells. J Breast Cancer (2016) 19:45-52. doi: $10.4048 / \mathrm{jbc}$.2016.19.1.45

190. Negri A, Naponelli V, Rizzi F, Bettuzzi S. Molecular Targets of Epigallocatechin-Gallate (EGCG): A Special Focus on Signal Transduction and Cancer. Nutrients (2018) 10. doi: 10.3390/nu10121936

191. Chu C, Deng J, Man Y, Qu Y. Green Tea Extracts Epigallocatechin-3-gallate for Different Treatments. BioMed Res Int (2017) 2017:5615647. doi: 10.1155/ $2017 / 5615647$

192. Chakrawarti L, Agrawal R, Dang S, Gupta S, Gabrani R. Therapeutic Effects of EGCG: A Patent Review. Expert Opin Ther Pat (2016) 26:907-16. doi: 10.1080/13543776.2016.1203419

193. Li Y, Buckhaults P, Cui X, Tollefsbol TO. Combinatorial Epigenetic Mechanisms and Efficacy of Early Breast Cancer Inhibition by Nutritive Botanicals. Epigenomics (2016) 8:1019-37. doi: 10.2217/epi-2016-0024

194. Borutinskaite V, Virksaite A, Gudelyte G, Navakauskiene R. Green Tea Polyphenol EGCG Causes Anti-Cancerous Epigenetic Modulations in Acute Promyelocytic Leukemia Cells. Leuk Lymphoma (2018) 59:469-78. doi: 10.1080/10428194.2017.1339881

195. O'Neill EJ, Termini D, Albano A, Tsiani E. Anti-Cancer Properties of Theaflavins. Molecules (2021) 26. doi: 10.3390/molecules 26040987

196. Takemoto M, Takemoto H. Synthesis of Theaflavins and Their Functions. Molecules (2018) 23. doi: 10.3390/molecules 23040918

197. He HF. Research Progress on Theaflavins: Efficacy, Formation, and Preparation. Food Nutr Res (2017) 61:1344521. doi: 10.1080/16546628.2017.1344521

198. Juarez-Mercado KE, Prieto-Martinez FD, Sanchez-Cruz N, Pena-Castillo A, Prada-Gracia D, Medina-Franco JL. Expanding the Structural Diversity of DNA Methyltransferase Inhibitors. Pharmaceuticals (Basel) (2020) 14:17. doi: $10.3390 / \mathrm{ph} 14010017$ 
199. Bhattacharya R, Chatterjee R, Mandal AKA, Mukhopadhyay A, Basu S, Giri AK, et al. Theaflavin-Containing Black Tea Extract: A Potential DNA Methyltransferase Inhibitor in Human Colon Cancer Cells and Ehrlich Ascites Carcinoma-Induced Solid Tumors in Mice. Nutr Cancer (2020) 1-13. doi: $10.1080 / 01635581.2020 .1828943$

200. Nomi Y, Iwasaki-Kurashige K, Matsumoto H. Therapeutic Effects of Anthocyanins for Vision and Eye Health. Molecules (2019) 24:3311. doi: 10.3390/molecules24183311

201. Rozanska D, Regulska-Ilow B. The Significance of Anthocyanins in the Prevention and Treatment of Type 2 Diabetes. Adv Clin Exp Med (2018) 27:135-42. doi: 10.17219/acem/64983

202. Lin BW, Gong CC, Song HF, Cui YY. Effects of Anthocyanins on the Prevention and Treatment of Cancer. Br J Pharmacol (2017) 174:1226-43. doi: 10.1111/bph.13627

203. Kuo HD, Wu R, Li S, Yang AY, Kong AN. Anthocyanin Delphinidin Prevents Neoplastic Transformation of Mouse Skin JB6 P+ Cells: Epigenetic Re-activation of Nrf2-ARE Pathway. AAPS J (2019) 21:83. doi: 10.1208/s12248-019-0355-5

204. Li S, Li W, Wang C, Wu R, Yin R, Kuo HC, et al. Pelargonidin Reduces the TPA Induced Transformation of Mouse Epidermal Cells -Potential Involvement of Nrf2 Promoter Demethylation. Chem Biol Interact (2019) 309:108701. doi: 10.1016/j.cbi.2019.06.014

205. Zhang H, Guo J, Mao L, Li Q, Guo M, Mu T, et al. Up-Regulation of miR-24$1-5 p$ is Involved in the Chemoprevention of Colorectal Cancer by Black Raspberry Anthocyanins. Br J Nutr (2019) 122:518-26. doi: 10.1017/ S0007114518003136

206. Wang TH, Hsia SM, Shih YH, Shieh TM. Association of Smoking, Alcohol Use, and Betel Quid Chewing With Epigenetic Aberrations in Cancers. Int $J$ Mol Sci (2017) 18:1210. doi: 10.3390/ijms18061210

207. Bjornsson HT, Sigurdsson MI, Fallin MD, Irizarry RA, Aspelund T, Cui H, et al. Intra-Individual Change Over Time in DNA Methylation With Familial Clustering. JAMA (2008) 299:2877-83. doi: 10.1001/jama.299.24.2877

208. Puthenveetil A, Dubey S. Metabolic Reprograming of Tumor-Associated Macrophages. Ann Transl Med (2020) 8:1030. doi: 10.21037/atm-20-2037

209. Yerinde C, Siegmund B, Glauben R, Weidinger C. Metabolic Control of Epigenetics and Its Role in CD8(+) T Cell Differentiation and Function. Front Immunol (2019) 10:2718. doi: 10.3389/fimmu.2019.02718

210. Shukla S, Meeran SM, Katiyar SK. Epigenetic Regulation by Selected Dietary Phytochemicals in Cancer Chemoprevention. Cancer Lett (2014) 355:9-17. doi: 10.1016/j.canlet.2014.09.017

211. Zheng YZ, Chen DF, Deng G, Guo R. The Substituent Effect on the Radical Scavenging Activity of Apigenin. Molecules (2018) 23:1989. doi: 10.3390/ molecules 23081989
212. Nagai S, Matsumoto C, Shibano M, Fujimori K. Suppression of Fatty Acid and Triglyceride Synthesis by the Flavonoid Orientin Through Decrease of C/EBPdelta Expression and Inhibition of PI3K/Akt-FOXO1 Signaling in Adipocytes. Nutrients (2018) 10:130. doi: 10.3390/nu10020130

213. Busch C, Burkard M, Leischner C, Lauer UM, Frank J, Venturelli S. Epigenetic Activities of Flavonoids in the Prevention and Treatment of Cancer. Clin Epigenet (2015) 7:64. doi: 10.1186/s13148-015-0095-Z

214. Rossi M, Edefonti V, Parpinel M, Lagiou P, Franchi M, Ferraroni M, et al. Proanthocyanidins and Other Flavonoids in Relation to Endometrial Cancer Risk: A Case-Control Study in Italy. Br J Cancer (2013) 109:1914-20. doi: $10.1038 /$ bjc.2013.447

215. Carrera AN, Grant MKO, Zordoky BN. CYP1B1 as a Therapeutic Target in Cardio-Oncology. Clin Sci (Lond) (2020) 134:2897-927. doi: 10.1042/CS20200310

216. Tse C, Warner A, Farook R, Cronin JG. Phytochemical Targeting of STAT3 Orchestrated Lipid Metabolism in Therapy-Resistant Cancers. Biomolecules (2020) 10:1118. doi: 10.3390/biom10081118

217. Zubair H, Azim S, Ahmad A, Khan MA, Patel GK, Singh S, et al. Cancer Chemoprevention by Phytochemicals: Nature's Healing Touch. Molecules (2017) 22:395. doi: 10.3390/molecules22030395

218. Vanden Berghe W. Epigenetic Impact of Dietary Polyphenols in Cancer Chemoprevention: Lifelong Remodeling of Our Epigenomes. Pharmacol Res (2012) 65:565-76. doi: 10.1016/j.phrs.2012.03.007

219. Mai A, Cheng D, Bedford MT, Valente S, Nebbioso A, Perrone A, et al. Epigenetic Multiple Ligands: Mixed Histone/Protein Methyltransferase, Acetyltransferase, and Class III Deacetylase (Sirtuin) Inhibitors. J Med Chem (2008) 51:2279-90. doi: 10.1021/jm701595q

220. Zheng YG, Wu J, Chen Z, Goodman M. Chemical Regulation of Epigenetic Modifications: Opportunities for New Cancer Therapy. Med Res Rev (2008) 28:645-87. doi: 10.1002/med.20120

221. George VC, Dellaire G, Rupasinghe HPV. Plant Flavonoids in Cancer Chemoprevention: Role in Genome Stability. J Nutr Biochem (2017) 45:114. doi: 10.1016/j.jnutbio.2016.11.007

Conflict of Interest: The authors declare that the research was conducted in the absence of any commercial or financial relationships that could be construed as a potential conflict of interest.

Copyright (c) 2021 Jiang, Xia, Liu, Li, Zhang and Sun. This is an open-access article distributed under the terms of the Creative Commons Attribution License (CC BY). The use, distribution or reproduction in other forums is permitted, provided the original author(s) and the copyright owner(s) are credited and that the original publication in this journal is cited, in accordance with accepted academic practice. No use, distribution or reproduction is permitted which does not comply with these terms. 